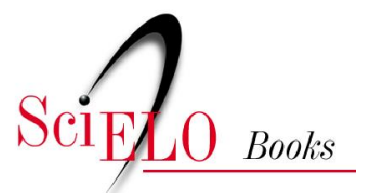

\author{
2 - Costa Ribeiro \\ da formação básica à Universidade
}

Wanderley Vitorino da Silva Filho

SciELO Books / SciELO Livros / SciELO Libros

SILVA FILHO, WV. Costa Ribeiro: da formação à Universidade. In: Costa Ribeiro: ensino, pesquisa e desenvolvimento da física no Brasil [online]. Campina Grande: EDUEPB; São Paulo: Livraria da Física, 2013, pp. 27-101. ISBN 9788578792763. Available from SciELO Books $<\underline{\text { http://books.scielo.org }>}$

\title{
@)(1)(9)
}

All the contents of this work, except where otherwise noted, is licensed under a Creative Commons Attribution-Non Commercial-ShareAlike 3.0 Unported.

Todo o conteúdo deste trabalho, exceto quando houver ressalva, é publicado sob a licença Creative Commons Atribuição Uso Não Comercial - Partilha nos Mesmos Termos 3.0 Não adaptada.

Todo el contenido de esta obra, excepto donde se indique lo contrario, está bajo licencia de la licencia Creative Commons Reconocimento-NoComercial-CompartirIgual 3.0 Unported. 


\section{2 \\ Costa Ribeiro: Da formação básica à Universidade}

\section{Introdução}

Joaquim da Costa Ribeiro nasceu no dia 8 de julho de 1906, no antigo Distrito Federal, capital brasileira, localizada àquela época no estado do Rio de Janeiro. Nasceu na casa, situada à Rua Barão de Itapejipe número $82 \mathrm{~A}$. Era filho do Doutor Antonio Marques da Costa Ribeiro e Maria Constança Albuquerque da Costa Ribeiro e herdou o nome de seu avô paterno - o Desembargador Doutor Joaquim da Costa Ribeiro. Cursou o ensino básico no tradicional Colégio Jesuíta, o Externato e Semi-Internato Santo Inácio, concluindo os seus estudos fundamentais em 1923, ingressando no ano seguinte na antiga Universidade do Rio de Janeiro.

\section{Universidade do Rio de Janeiro}

A universidade na qual Costa Ribeiro ingressou foi instituída por decreto ${ }^{2}$ do presidente Epitácio Pessoa, que reunia sob a denominação de Universidade do Rio de Janeiro instituições

2 Decreto $n^{\circ} 14343$ de 7 de setembro de 1920. 
de ensino superior, que datam sua criação no século XIX, sendo elas: a Escola Politécnica do Rio de Janeiro, a Faculdade de Medicina do Rio de Janeiro e a Faculdade de Direito do Rio de Janeiro.

Freitas (1995) apresenta os dois primeiros cursos superiores instituídos no Brasil. Foi no século XIX que foram criados os primeiros cursos superiores no Brasil, sendo o primeiro criado na Bahia. Devido à expansão napoleônica, a Corte portuguesa fugiu para uma de suas colônias de exploração - o Brasil - tornando-se a colônia a nova sede do Império Português. Ainda no período em que a Corte portuguesa se estabeleceu na Bahia, o príncipe regente de Portugal, Dom João VI, criou em 18 de fevereiro de 1808 a Escola de Cirurgia da Bahia. Meses depois, com a transferência da Corte portuguesa para o Rio de Janeiro, foi criada uma Cadeira de Anatomia, iniciando-se também naquela capitania o ensino da medicina. Foi a Carta Régia dirigida ao Governador e Capitão General da Capitania da Bahia, Dom Fernando José, o documento oficial que autorizou a implantação do ensino médico no Brasil. "Quatro anos depois, o cirurgião baiano Dr. Manuel Luiz Álvares de Carvalho elaborou um plano de estudos de Cirurgia, convertido em decreto de $1^{\circ}$ de abril de 1813; o plano ampliava o curso médico de quatro para cinco anos e dava a denominação de Academias Médico-Cirúrgicas a essas primitivas escolas" (idem, ibidem). Em 1831 "[...] a Carta de Lei da Assembléia Legislativa do Império, sancionada pela regência em nome do Imperador Dom Pedro II, aprovou o título de Escolas ou Faculdades de Medicina para as instituições" (idem, ibidem). No ano seguinte a Academia Médico-Cirúrgica da Bahia passou a ser denominada de Faculdade de Medicina da Bahia e a Academia Médico- 
Cirúrgica do Rio de Janeiro passou a ser Faculdade de Medicina do Rio de Janeiro. A Faculdade de Medicina da Bahia "abrigou os primeiros cursos de Farmácia, Odontologia e Enfermagem Obstetricia." (idem, ibidem). "Em 1946 passou a ser Faculdade de Medicina da Universidade da Bahia. Em 1974, para atender à reforma universitária (Lei de Diretrizes e Bases da Educação), as cátedras desapareceram e a Universidade foi departamentalizada [...]"(idem, ibidem). O prédio que abrigou a Escola de Cirurgia da Bahia"[...] foi construído pelos jesuítas em 1553 e abrigou, inicialmente, o Colégio da Companhia de Jesus [...]. Até 1755, o local abrigou, também, o Curso de Matemática. A partir de 1759, com a expulsão dos jesuítas, o conjunto ficou abandonado durante três décadas, até que, em 1787, instalouse ali a Régia Casa de Educação, onde eram ministradas aulas de Latim, Grego, Filosofia e Retórica. Em 1799, passou a funcionar no prédio o Real Hospital Militar [...]."(idem, ibidem), e finalmente em 1808 a Escola de Cirurgia, posteriormente "Curso Médico Cirúrgico da Bahia, precursor da primeira Faculdade de Medicina no Brasil, que foi instalada no antigo Colégio dos Jesuítas, em 1832." (idem, ibidem). Importantes documentos da história da antiga Faculdade de Medicina da Bahia foram recuperados, dentre eles um que nos interessa é o que trata das teses:

A partir de 1836, uma grande parte delas era em manuscritos, outras eram impressas. Dividem-se em três categorias: as de Doutoramento ou Inaugurais, estabelecidas por Decreto de 3 de outubro de 1832, o qual determinava que o 'candidato não obterá o grau de doutor sem sustentar em publico uma tese'. Escritas em latim ou português, constavam de 
um tema sugerido pela Congregação. Traziam, no final, aforismos de Hipócrates em latim ou em grego [...]. As Teses de Verificação de Título visavam à revalidação de diplomas para os diplomados em Medicina no exterior e que desejavam o titulo nacional de Doutor. As Teses de Concurso eram elaboradas para preenchimento dos lugares vagos de "lentes proprietários' e para 'concursos de opositores', professores substitutos (Decreto no. 1387, de 28 de abril de 1854). Essas tinham forma menos literária, refletindo o avanço metodológico e científico da época. Numerosos investigadores de renome nacional destacaram-se com a elaboração desses estudos. Citam-se, por exemplo, Antonio José Alves, pai do poeta Castro Alves, integrante do núcleo inicial da Escola Tropicalista, Pirajá da Silva, descobridor da esquistossomose, os irmãos Pacífico Pereira e Manoel Vitorino Pereira, este Presidente interino da República, Juliano Moreira, Raymundo do Nina Rodrigues, Oscar Freire, Prado Valadares, Clementino Fraga [...] (FREITAS, 1995).

Foi na Faculdade de Medicina da Bahia que em 1887 a Dra. Rita Lobato Velho, tornou-se a primeira mulher diplomada no Brasil.

A Faculdade de Medicina da Bahia não se notabilizou somente por ter sido a primeira instituição de ensino superior no Brasil, somente esse argumento seria pouco, dentre outras, uma importante contribuição veio da Escola Tropicalista Baiana. 
Edler (2002) trata do papel desempenhado por um grupo de médicos egressos da Faculdade de Medicina da Bahia, na segunda metade do século XIX. No artigo, Edler utiliza os trabalhos de Julian Peard ${ }^{3}$ pelo "[...]fato de ser o seu o mais completo e exaustivo estudo histórico a respeito dos médicos que se organizaram em torno da Gazeta Médica da Bahia, núcleo original das pesquisas em helmintologia médica" (idem, ibidem). Para Edler, um ponto que deve ser ressaltado em Peard

[...]se refere à sua desconfiança diante da imagem amplamente aceita pela historiografia, que apresenta os médicos brasileiros daquela época como reprodutores passivos da medicina européia e lentos em abraçar os modelos médicos que se encontravam no front da ciência. Tal imagem, argumenta a autora, teria sido sedimentada ainda nas primeiras décadas do século XX, quando se procurou criteriosamente 'esconder os episódios precedentes', voltados para a construção de tradições médicas locais. Seu trabalho teve por objetivo desvelar uma história deliberadamente encoberta pela geração de Oswaldo Cruz, revendo a interpretação, promulgada por esse grupo, de que o período anterior pertenceria à 'idade das trevas' da medicina' (idem, ibidem).

3 Tropical disorders and the forging of a Brasilian medical identity, 1860-1890; e The Tropicalist School of Medicine of Bahia, Brazil, 1869-1889 
Sobre os médicos baianos e o trabalho de Peard, Edler apresenta:

[...] Julian Peard desenvolve um estudo aprofundado sobre um grupo de médicos baianos que, na segunda metade do século XIX, 'inicialmente fora do ambiente institucional', ajudou a disseminar 'novas idéias sobre saúde e doença no Brasil'. A Escola Tropicalista Baiana, como tal grupo ficou conhecido, notabilizou se por seus trabalhos sobre beribéri, ancilostomíase, filariose e ainhum - doenças associadas ao clima tropical. Peard postula ainda que, em contraste com as idéias de medicina tropical desenvolvidas pelas potências coloniais européias, os tropicalistas teriam forjado sua própria definição de medicina tropical, baseados na crença otimista sobre a possibilidade de se construir um lugar para o Brasil ao lado das nações civilizadas, apesar de seu clima e do povo miscigenado.

[...] ela assinala que a recusa do estereótipo dos trópicos como região deletéria para o europeu, 'bastante disseminada desde o século XVIII', conduziu à produção de um conhecimento original por parte desses médicos organizados em torno da Gazeta Médica da Bahia, em bases não formalmente institucionalizadas, bem antes do advento dos institutos de medicina tropical. Teorias raciais, como o poligenismo, bastante vulgarizado nos Estados Unidos, foram rejeitadas por uma sociedade miscigenada, em que 
muitos médicos eram mulatos ou negros. Por outro lado, 'ainda que não declaradamente lamarckistas', os médicos da Bahia valorizavam a maleabilidade e adaptabilidade dos seres humanos, em contraposição ao determinismo climático amplo. 'Esta concepção da natureza humana possibilitava que os tropicalistas desenvolvessem um modelo etiológico flexível que punha ênfase no papel dos médicos na preservação e recuperação da saúde de seus pacientes'.

[..] Peard demonstra inequivocamente que a etiologia ambientalista não conduzia necessariamente a um determinismo pessimista sobre o clima tropical por parte daqueles médicos brasileiros. Ao investigar as doenças típicas do meio tropical, os tropicalistas da Bahia utilizaram os mais avançados instrumentos da medicina européia, tal como a 'estatística médica, os novos métodos clínicos baseados na medição e na fisiologia aplicada, o uso da química na análise das partes fluidas do corpo, particularmente no campo da hematologia, a nascente parasitologia e, sobretudo, a microscopia, cuja utilização foi pioneira na Bahia'. Cada um desses instrumentos, ela argumenta, os diferenciava da medicina vigente. Os tropicalistas teriam rejeitado o antigo modo de interpretar as doenças tropicais a partir de difusos fatores ambientais, "impondo um novo modelo científico, o qual mudava o foco de suas pesquisas do meio ambiente para doenças individuais e específicas'. Teria sido essa nova orientação 
de seus trabalhos que os levou a serem aclamados internacionalmente e imprimiu a eles uma identidade mais vigorosa como movimento médico. (EDLER, 2002).

Retornando à Universidade do Rio de Janeiro, o ato do Presidente Epitácio Pessoa dava continuidade ao dispositivo previsto no decreto ${ }^{4}$ assinado pelo Presidente Wenceslau Braz, que reorganizou o ensino secundário e superior na República Brasileira. O dispositivo deixava ao Governo Federal, quando achasse oportuno, reunir em universidade a Escola Politécnica e a Escola de Medicina do Rio de Janeiro, incorporando-lhes uma das Faculdades Livres de Direito, e não especificamente a da capital da República, como aconteceu.

O que se realizou ao denominar de Universidade do Rio de Janeiro, foi estabelecer uma ligação jurídica entre as faculdades ou escolas já existentes. Não foram reunidas em uma única sede, por exemplo; mantiveram-se em atividade onde já funcionavam. Com o nome de universidade passou a ser composta pelos sete cursos previamente existentes: Odontologia, Farmácia, Medicina, Direito, Engenharia Mecânica e de Eletricidade, Engenharia Civil e Engenharia Industrial.

Das opções que tinha, o jovem Costa Ribeiro optou pela Escola Politécnica, que reunia os cursos das engenharias. Um expediente realizado na Escola Politécnica, nesse período, era agraciar com o que se denominou de prêmios, alunos que conseguissem obter as maiores médias entre seus colegas. Pelo mérito de médias, Costa Ribeiro chegou a receber alguns

4 Decreto no 11530 de 18 de março de 1915. 
prêmios oferecidos pela Escola Politécnica sendo eles: Gomes Jardim, Morsing e Dr. Paulo de Frontin. Recebeu também o prêmio Conselheiro Pitanga por obter a maior média em Física, sendo que a Física ministrada para engenheiros tinha o caráter meramente profissionalizante. $O$ ciclo estudantil finalizou para Costa Ribeiro no primeiro quartel de 1929, quando se graduou Engenheiro Civil.

Foi no magistério que Costa Ribeiro iniciou-se profissionalmente, no dia e na instituição em que se diplomou. Foi nomeado assistente interino da Cadeira de Mecânica Industrial durante a primeira metade letiva desse ano, período do seu contrato. Ao final do citado período e já na segunda metade do mencionado ano letivo, foi contratado como assistente da Cadeira de Fisica Experimental cujo catedrático era o engenheiro Cândido Alberto Pereira. Foi o mencionado catedrático que propôs à diretoria da Escola Politécnica a contratação de Costa Ribeiro, para assumir aquela função durante o impedimento do mencionado engeneheiro em realizar suas atividades docentes.

Dias antes de vencer o segundo contrato, o que ocorreria no último dia do já referido ano, Costa Ribeiro foi nomeado para o cargo de auxiliar técnico da Diretoria Geral de Estatística (DGE), que inicialmente estava subordinada ao Ministério da Agricultura, Indústria e Comércio.

A Diretoria estava encarregada de fazer o recenseamento durante o novo ano que se apontava. o trabalho durou treze meses aproximadamente, quando seu diretor deu por encerrada as atividades da Diretoria, que na ocasião já estava subordinada ao Ministério do Trabalho, Indústria e Comércio. O encerramento das atividades da DGE, que sequer foi concluído, deveu-se 
à falta de recursos para a manutenção de seus serviços; contudo, mesmo com as adversidades financeiras, Costa Ribeiro participou da organização do cadastro predial do Distrito Federal.

A década de trinta já havia surgido - quando em meados do seu primeiro ano - o ainda auxiliar técnico da DGE retornou ao magistério após prestar concurso para a Cadeira de Física e Química em estabelecimento de Ensino Profissional ${ }^{5}$ da prefeitura de sua cidade natal.

\section{O trabalho docente e a Universidade}

Em novembro de 1931, Costa Ribeiro retornou como assistente (e não mais interino) da Cadeira de Física da Escola Politécnica. Os assistentes faziam parte do quadro dos auxiliares de ensino, mas pertencentes ao corpo docente, e eram nomeados pelo diretor da Escola mediante proposta do professor catedrático e autorização do conselho técnico administrativo. De fato, os assistentes exerciam o papel de professores assistentes, ministrando aulas no lugar e por indicação do catedrático, inclusive. Deveriam dedicar de seis a dez horas semanais às funções para a qual foram contratados. Tinham ainda como atribuições: comparecer com antecedência às aulas e disponibilizar, segundo indicações do professor, material necessário às demonstrações do curso e aos trabalhos práticos; acompanhar e fiscalizar os trabalhos práticos nos laboratórios e gabinete, bem como os demais exercícios escolares e zelar pela conservação do material a serviço da Cadeira.

5 Em 1934 este cargo passou a denominar-se Professor de Escolas Técnicas Secundárias, pertencente à seção de ciências naturais e higiene do Departamento de Educação, conforme decreto nº 4779 de 16 de maio de 1934. 
O assistente que ainda não fosse Docente Livre da Cadeira, como era o caso de Costa Ribeiro, após dois anos da nomeação, deveria se submeter ao concurso para obtenção do referido título, sob a pena de perda automática do cargo e de não poder ser nomeado assistente de outra cátedra até obter o mesmo. Findando o prazo estipulado em lei, ele se inscreveu então no concurso para obtenção do título citado.

Para obter o título de docente livre, era necessário realizar as provas escrita, prática (ou experimental), didática e de títulos. O julgamento do concurso era realizado por uma comissão composta por cinco membros. Desses, dois eram indicados pela congregação; e três outros escolhidos pelo conselho técnico-administrativo dentre professores de outros institutos de ensino superior ou profissionais especializados de instituições técnicas ou científicas.

A comissão que julgou o concurso para a obtenção do título, para o qual Costa Ribeiro era candidato, tinha como componentes: Francisco Ferreira Ramos, C. de A. Martins Costa, Dulcídio Pereira, Jorge Leuzinger e J. Pantoja Leite.

Para a sua prova escrita foram sorteados os seguintes pontos: "Estudo especial da refração (medida dos índices, fotometria)"; "fonte de luz"; e "campo magnético das correntes". Sobre esta prova, assim foi descrita pela comissão:

O candidato tratou muito bem do assunto, apresentando uma prova impecável como método, clareza e exposição. Antes de entrar no assunto fez uma série de considerações muito oportunas sobre o assunto da física, que bem revelam o valor pedagógico do candidato. A comissão se julga satisfeita com esta prova. 
Na prova prática, o ponto sorteado foi "Medida da densidade de vapor". Na prova ele deveria determinar a densidade do vapor do líquido dado, indicando o grau de precisão da medida e as aplicações de tal determinação. $O$ líquido utilizado foi o tetracloreto de carbono. Assim foi o parecer da comissão:

O candidato conduziu bem a manipulação, tendo com propriedade escolhido o método de Victor Mayer. Efetuou uma série de medidas, tendo no fim quebrado o tubo de vidro do aparelho. Achou números muito próximos do verdadeiro, tendo calculado a massa molecular da substância dada, com suficiente aproximação. Indicou a ordem de grandeza dos erros a temer e o grau de precisão das medidas que efetuou. 0 relatório está muito bem apresentado. A comissão se satisfez com esta prova.

Finalmente, a prova oral teve como tema, "soluções diluídas". Parecer:

O candidato realizou uma preleção que a comissão julga muito boa, pela elevação, método, clareza e ordem. Iniciou as experiências e manipulações que deviam ser executadas, revelando também nesta prova qualidades pedagógicas que a comissão julga dever salientar.

Ao final do concurso, Costa Ribeiro foi habilitado à docência livre na Cadeira de Física da Escola Politécnica, obtendo o título em novembro de 1933. 
Em janeiro do ano seguinte Costa Ribeiro se casou com Jacqueline de Leers, que passou a se chamar Jacqueline de Leers Costa Ribeiro. Ainda nesse ano, Costa Ribeiro foi nomeado auxiliar técnico da Diretoria Nacional de Educação da Secretaria de Estado da Educação e Saúde Pública, tomando posse no mesmo mês da nomeação, setembro.

Em novembro de 1935, o auxiliar técnico Costa Ribeiro foi designado pelo Diretor Geral de Educação, Paulo de Assis Ribeiro, para fazer a inspeção preliminar na Universidade do Distrito Federal (UDF), criada no início do citado ano, dos seguintes pontos ${ }^{6}$ :

I, ter tido funcionamento regular e efetivo anterior ao pedido de inspeção preliminar, e caso uma existência suficiente o permita, deve [ser] exigido que este funcionamento se tenha verificado nos dois anos imediatamente anteriores ao pedido;

II, observar regime didático e escolar idêntico ao de instituto oficial congênere;

III, dispôr de edifícios e instalações apropriadas ao ensino a ser ministrado;

IV, possuir corpo docente idôneo no ponto de vista moral e científico;

$\mathrm{V}$, instituir o provimento por concurso das vagas que ocorreram no corpo docente, a partir do início da inspeção preliminar;

6 Conforme decreto $n^{\circ} 20.179$ de 6 de julho 1931 e decreto $n^{\circ} 23.546$ de 5 de dezembro 1933. 
VI, dispôr de fontes de rendas próprias para a garantia de regular funcionamento pelo prazo mínimo de três anos;

VI, possuir administração e escrita financeira regularmente organizadas;

VIII, limitar a matrícula, em cada série do curso, de acôrdo com a capacidade didática das instalações.

Após a inspeção, caberia ao auxiliar técnico fazer relatório a ser submetido ao Conselho Nacional de Educação, que deveria decidir sobre o reconhecimento dos diplomas expedidos pelos institutos de ensino superior, no caso a UDF, como válidos para o exercício profissional no território da República. Tal procedimento obedecia aos trâmites necessários às novas instituições de ensino superior (Institutos Livres, Escolas Livres ou Faculdades) que se instalavam no país. Costa Ribeiro foi designado para executar tais atividades ainda na Escola de Arquitetura de Belo Horizonte em 1937. A partir de 1938 passou a ser comissionado para exercer função semelhante a de auxiliar técnico, já que a partir do referido ano não era mais permitido ao funcionário público acumular funções remuneradas, assunto que será tratado ainda no capítulo 2. Em 1938 fez parte da comissão designada pelo Ministério da Educação e Saúde, à frente o ministro Gustavo Capanema, para proceder a verificação sobre a organização e funcionamento da Escola de Belas Artes de São Paulo. Em 1939 foi designado para a mesma comissão com o fito de verificar junto à Faculdade de Filosofia e no ano seguinte as Faculdades Católicas de Filosofia e de Direito, que requeriam autorização para funcionamento junto ao ministério já citado. 
Em 1938 foi baixado decreto ${ }^{7}$ que dispunha sobre o sistema legal de unidades de medida e sobre o uso de medidas e instrumentos de medir, criando também a Comissão de Metrologia. Tal decreto foi instituído, pois se considerava que a legislação vigente no Brasil sobre pesos e medidas ${ }^{8}$ já se tornara, além de antiquada, técnica e juridicamente inaplicável. Costa Ribeiro foi um dos participantes da comissão redatora do projeto de regulamentação de que tratava o referido decreto, sob a responsabilidade do Instituto Nacional de Tecnologia (INT). Sobre esses trabalhos, o físico Bernhard Gross enfatiza:

[...] eu passei a ser, acho que diretor da Divisão de Metrologia[...]. Então, fez-se o Regulamento de Metrologia. Na lei não tivemos participação, pelo que me lembro, mas no regulamento sim. Inclusive o Costa Ribeiro fez a tabela de unidades. É uma tabela que dava os nomes, os símbolos e os valores das diferentes unidades, que eram anexas à lei (GROSS,1976).

Concluído os trabalhos, em janeiro do ano seguinte, Costa Ribeiro entregou-os à Comissão de Metrologia, subordinada Ministério do Trabalho, Indústria e Comércio. Em 1942 o citado autor foi designado para exercer a função de membro consultor da Comissão de Metrologia e no ano seguinte a de professor de Física do curso de formação de metrologistas.

7 Decreto - lei n. 592 de 4 de agosto 1938.

8 As unidades componentes do sistema de medidas legal no Brasil são as adotadas nas Conferências Gerais de Pesos e Medidas, reunidas por força da Convenção Internacional do Metro, de 20 de maio de 1875. 


\section{O início da Era Vargas e a Universidade do Distrito Federal}

Naturalmente, Costa Ribeiro presenciava os acontecimentos da década de 1930, que teriam influências na sua carreira docente. Ao se transitar pela referida década, não se pode ficar alheio aos acontecimentos surgidos pela chegada de Getúlio Vargas ao poder político central brasileiro. Vargas, ao se tornar Presidente, em novembro de 1930, nomeou interventores federais para administrar estados e capitais brasileiras. Tais interventores faziam parte do conjunto que o apoiou e o conduziu à Presidência da República, que culminou na saída do Presidente Washington Luís e no impedimento da posse do candidato Júlio Prestes, eleito no pleito de março de 1930. Assim, Vargas, após a revolução de 1930, pôs fim à política velada conhecida como Café com Leite. Entre os interventores nomeados por Vargas, estava o médico Pedro Ernesto Batista, que administrou o Distrito Federal entre 1931 e 1935. Para criar uma imagem do período em que Pedro Ernesto esteve à frente da Prefeitura do Distrito Federal, recorremos a Cachapuz (2001).

Natural de Recife, o interventor Pedro Ernesto nasceu no dia 25 de setembro de 1884 . Seu pai, um pequeno comerciante na capital pernambucana e líder maçônico exerceu influência marcante em sua formação. Ele completou seus estudos básicos na sua cidade natal e iniciou o curso de Medicina em Salvador, concluindo-o em 1908 no Distrito Federal. No ano seguinte casou-se com Maria Evangelina Duarte Batista. Em 1918 fundou a casa de saúde Pedro Ernesto especializada em obstetrícia, cirurgia e ginecologia. Sendo considerado um 
excelente cirurgião ele alcançou, rapidamente, grande reputação e prosperidade. Em 1924 inaugurou um hospital mais espaçoso e melhor equipado, construído com o apoio de comerciantes portugueses.

Em 1922, Pedro Ernesto aderiu ao primeiro levante tenentista conhecido como a Revolta do Forte de Copacabana, deflagrado em 5 de julho na então capital brasileira. Através do capitão João Aníbal Duarte, primo de sua esposa e ajudante de ordens do marechal Hermes da Fonseca (Sobre Hermes da Fonseca havia uma ordem de prisão dada pelo presidente Epitácio Pessoa e que foi o estopim da revolta) associou-se ao movimento sem, contudo, ter tido participação direta. Em outubro de 1924 aliou-se à conspiração chefiada pelo capitão-de-mar e guerra Protógenes Guimarães que pretendia mobilizar os integrantes dos navios da esquadra ancorados na baía de Guanabara, em apoio ao movimento chamado Segundo 5 de julho, outro levante tenentista ocorrido, porém, em São Paulo, que tinha como objetivo final derrubar o presidente Arthur Bernardes. Protógenes e Pedro Ernesto foram presos; o último foi solto, poucos dias depois, devido à interferência de seu tio-avô André Cavalcante, presidente do Supremo Tribunal Federal entre 1924 e 1927.

Enquanto a Coluna Prestes percorria o interior do Brasil para escapar do cerco imposto pelo Exército Brasileiro, eclodiam pelo país várias tentativas de rebelião, uma delas ocorrida em maio de 1925 no Rio de Janeiro, sucumbindo ao fracasso. Pedro Ernesto fez, então, de sua casa de saúde um ponto de refúgio para os "tenentes" perseguidos pela polícia e ponto de encontro, até a vitória da revolução de 1930, prestando socorros médicos aos revolucionários. Em 1929 o presidente Washington 
Luís passou por cirurgia tendo como médico cirurgião o próprio Pedro Ernesto, que tinha seu hospital constantemente invadido pela polícia.

Em 1929 Pedro Ernesto aderiu à Aliança Liberal, coalizão formada pelos estados de Minas Gerais, Rio Grande do Sul e Paraíba, a fim de concorrer ao pleito eleitoral de março de 1930, que tinha como candidato a presidente Getúlio Vargas, do Rio Grande do Sul, e vice-presidente João Pessoa, da Paraíba. Pedro Ernesto participou da campanha de Getúlio Vargas no Rio de Janeiro. Com a derrota da Aliança Liberal, ele participou, ativamente, do levante revolucionário que depôs o presidente Washington Luiz, em 24 de outubro de 1930, e que conduziu Vargas, em 3 de novembro, ao poder político central brasileiro.

Em novembro, Pedro Ernesto foi nomeado por Vargas diretor da Assistência Hospitalar do Distrito Federal. Tornou-se também médico particular do Presidente, chegando a salvar a vida de Lutero Vargas - filho de Getulio Vargas - ferido em um acidente de automóvel. Evitou também a amputação da perna da esposa do Presidente, Darci Vargas, envolvida em outro acidente de automóvel.

Em setembro de 1931 Pedro Ernesto foi designado, por Vargas, interventor no Distrito Federal. Em 1933 participou da comissão organizadora do Partido Autonomista do Distrito Federal fundado em março daquele ano. Dois meses depois de sua fundação, o Partido Autonomista elegeu seis dos dez representantes do Rio de Janeiro à assembléia constituinte. Projetava-se então como líder partidário de maior influência no Distrito Federal. Com estilo próprio de administração foi considerado como o precursor do populismo empregado por Vargas anos 
mais tarde, de quem foi partidário na eleição para a presidência da república, pela Assembléia Constituinte, o que ocorreu em julho de 1934, bem como a promulgação da constituição. Para outubro do mesmo ano estavam marcadas as eleições legislativas e o Partido Autonomista obteve grande vitória sobre o seu principal adversário, o Partido Economista, elegendo 8 dos 10 representantes do Rio de Janeiro para a câmara dos deputados e 20 dos 24 representantes para a câmara municipal. Com ampla representação, os vereadores do Partido Autonomista elegeram Pedro Ernesto prefeito do Distrito Federal, tornando-o o primeiro governante eleito, indiretamente, da capital brasileira.

Como interventor e como prefeito, Pedro Ernesto teve uma administração marcada por importantes realizações, principalmente na área da educação e da saúde. No início da década de 1930, o Rio de Janeiro dispunha de uma população de um milhão e meio de habitantes e uma rede de escolas e hospitais precários. À frente da Diretoria Geral de Instrução Pública, Pedro Ernesto tinha Anísio Teixeira, defensor de um sistema escolar público, gratuito, obrigatório e leigo. Durante o período em que foi diretor, Teixeira construiu 30 escolas e fez uma ambiciosa reforma educacional. Pedro Ernesto também era contrário ao ensino religioso nas escolas públicas, motivo pelo qual sofreu duras críticas dos meios católicos, quando se opôs ao projeto de introdução do ensino religioso, no início de 1935. No departamento de saúde, Pedro Ernesto contou com Gastão Guimarães que entre as realizações estavam o reequipamento da rede hospitalar, a construção dos hospitais Getúlio Vargas, Carlos Chagas e Miguel Couto e vários centros de saúde. Também foram realizadas obras de saneamento que melhoraram sensivelmente as condições sanitárias da cidade, em especial nos bairros dos subúrbios. 
Em março de 1935, Pedro Ernesto cedeu à Aliança Nacional Libertadora (ANL), o teatro João Caetano para que o referido grupo político fizesse sua sessão inaugural. Mesmo com a aprovação da Lei de Segurança Nacional, em abril do mesmo ano, ele assegurava liberdade de atuação da ANL na capital do país. Em maio cedeu o Instituto de Educação à União Feminina do Brasil para uma manifestação contra o fascismo. Após tal fato, apoiou a criação da União Trabalhista do Distrito Federal, entidade composta por dirigentes sindicais e por intelectuais ligados à ANL. Em junho do mesmo ano condenou o fechamento da ANL.

Em novembro de 1935 ocorreu a Intentona Comunista, com levantes em algumas capitais brasileiras e, em particular, no Rio de Janeiro, sucumbindo ao fracasso. Pedro Ernesto passou, então, a ser um dos principais alvos da campanha anticomunista, bem como seu secretário de educação, Anísio Teixeira. Além de não ter participação no levante, Pedro Ernesto avisou ao presidente Vargas em 26 de novembro daquele ano da iminente deflagração.

Em fevereiro de 1936, o presidente da Comissão Nacional de Combate ao Comunismo, o deputado Adalberto Correia, propôs a Vicente Rios, Ministro da Justiça, as prisões de Anísio Teixeira, Pedro Ernesto e seu filho Odilon Bastos, o que não ocorreu.

Em abril do mesmo ano, Pedro Ernesto foi preso, assumindo a prefeitura - interinamente - o padre Olímpio de Melo, presidente da Câmara Municipal, eleito pelo Partido Autonomista, e com quem Pedro Ernesto já não possuía boas relações. Ao aproximar-se o julgamento de Pedro Ernesto, Vargas nomeou Olímpio Melo como interventor no Distrito Federal, em março de 1937. Em julho, Olímpio Melo renunciou ao cargo de interventor, 
sendo nomeado em seu lugar Henrique Dodsworth, do Partido Economista Democrático. Pedro Ernesto enfim foi julgado em maio juntamente com outros acusados do levante comunista de 1935 e, apesar de negar as acusações de apoio e participação ao levante, foi condenado a três anos e quatro meses de prisão. Em setembro foi absolvido pelo Supremo Tribunal Militar, sendo solto. Ao sair anunciou sua adesão à candidatura de Armando Sales de Oliveira à Presidência da República em 1938, que não ocorreu devido ao Estado Novo. Em outubro, após o forjado Plano Cohen, que tinha como falso objetivo a derrubada do Governo pelos comunistas, entrou em vigor o estado de guerra. Pedro Ernesto seguiu então para São Paulo, dias depois, a fim de comunicar ao general executor do estado de guerra, naquela unidade da federação, a sua viagem à Argentina (com o intuito de se exilar). Foi preso após o general entrar em contato com seus superiores. O seu filho, que se encontrava na capital brasileira, também foi preso. Pedro Ernesto foi solto em janeiro de 1938, retornando ao Rio de janeiro após cumprir prisão domiciliar em Campanha (MG). Passou ainda por um processo humilhante, quando foi acusado por desvio de material da prefeitura, juntamente com outros funcionários, sendo julgado e absolvido em agosto de 1939. Faleceu no Rio de Janeiro em agosto de 1942. Seu sepultamento foi marcado por homenagens oficiais e grande manifestação popular.

Em Rocha (1992) encontra-se a experiência administrativa de Anísio Teixeira antes de assumir a Diretoria Geral de Instrução Pública do Distrito Federal.

Natural de Caetité, Bahia, Anísio Spínola Teixeira nasceu em 12 de julho de 1900 e era filho do fazendeiro Deocleciano Pires Teixeira e de Ana Spínola Teixeira. Ele iniciou seus estudos na 
sua cidade natal, concluindo em Salvador o curso secundário no tradicional colégio católico Antônio Vieira, entrando em seguida no curso de direito na capital baiana e concluindo-o no Distrito Federal em 1922. Foi nomeado em 1924 pelo governador Góis Calmon, Inspetor Geral do Ensino na Bahia, revelando-se grande administrador, reformulando o sistema educacional, dobrando o orçamento destinado à educação e triplicando o número de matrículas no sistema educacional. Em 1925 e 1927, viaja à Europa e aos Estados Unidos, respectivamente, a fim de conhecer novos sistemas de ensino com o objetivo de aperfeiçoar os serviços de educação na Bahia. Permaneceu à frente do órgão educacional até 1928 quando retornou aos Estados Unidos para realizar o curso de pós-graduação no Teachers College da Columbia University, obtendo no ano seguinte o título de Master of Arts. Nesse período conheceu o filósofo e educador John Dewey, cujas ideias passou a difundir - no Brasil - ao longo de sua vida.

Em outubro de 1931 Anísio Teixeira foi nomeado Diretor Geral de Instrução Pública do Distrito Federal, substituindo seu amigo, o educador Fernando de Azevedo, permanecendo no cargo até 1935, ano em que a referida Diretoria foi transformada em Secretaria Geral de Educação e Cultura (FÁVERO e LOPES, 2009).

Anísio Teixeira era um dos mais ilustres representantes da ala dos liberais da Associação Brasileira de Educação (ABE), que desde 1922 esteve à frente do órgão municipal de educação do Distrito Federal, realizando importantes reformas, tal como os seus antecessores Carneiro Leão, à frente da referida Diretoria entre 1922 e 1926, que reformulou o ensino primário, e Fernando de Azevedo, de 1927 a 1931 (LEITE LOPES, 2004). 
À frente do órgão educacional, Anísio Teixeira organizou a rede municipal de ensino da pré-escola à universidade. A estruturação do ensino público na capital brasileira não foi tarefa fácil, e o mencionado Diretor Geral a fez em meio a conflitos de ideias e de interesses de seus opositores - os conservadores da educação - mas recebeu também o apoio de personagens respeitáveis do magistério da capital da República. Em 1935 ele atinge o ápice de sua estruturação ao criar a Universidade do Distrito Federal, motivo pelo qual passou a sofrer, abertamente, fortes ataques do seu opositor, o líder católico Alceu Amoroso Lima. Este o acusava de ser simpatizante da ANL e de pretender implantar uma educação socialista na capital da República. Tal oposição fica clara, quando, em junho deste mesmo ano, Amoroso Lima envia uma carta ao Ministro Gustavo Capanema situando a posição dos católicos e cobrando do Governo medidas enérgicas de repressão ao comunismo. Em tal carta, Amoroso Lima considera indispensável ao Governo "organizar a educação e entregar os postos de responsabilidade nesse setor importantíssimo a homens de toda confiança moral e capacidade técnica, e não a socialistas como o Diretor do Departamento Municipal de Educação" (Amoroso Lima, 1935 apud FÁVERO e LOPES, 2009), uma referência direta a Anísio Teixeira. A oposição do citado líder católico à criação da UDF fica registrada na citada carta:

O espetáculo do Brasil de hoje ofereceu-nos a oportunidade de algumas considerações, que sou levado a repetir-lhe por carta, não só pela nossa velha amizade, mas ainda por ser você a mais alta autoridade de nossa organização educativa. A recente fundação de uma Universidade Municipal, com a nomeação de certos diretores de Faculdades que não 
escondem suas ideias e pregação comunistas, foi a gota d'água que fez transbordar a grande inquietação dos católicos.

Para onde iremos por esse caminho? Consentirá o governo em que, à sua revelia mas sob sua proteção, se prepare uma geração inteiramente formada dos sentimentos mais contrários à verdadeira tradição do Brasil e aos verdadeiros ideais de uma sociedade sadia? (FÁVERO e LOPES, 2009)

Não somente Anísio Teixeira foi perseguido por Amoroso Lima. O líder católico já havia estado em cena quando se opôs veementemente à nomeação de Fernando de Azevedo para a Diretoria Nacional de Educação, ameaçando - caso ocorresse tal indicação - cessar toda colaboração com o Ministério da Educação. Tal atitude não era uma novidade por parte da ala católica. Em abril de 1931, o então Ministro da Educação Francisco Campos enviou carta a Getúlio Vargas explicando um decreto $^{9}$ que deveria ser assinado pelo Presidente, tornando facultativo o ensino religioso nas escolas oficiais e favorecendo a Igreja Católica, que seria mobilizada ao lado do Governo para apreciá-lo, colocando a serviço dessa mobilização a opinião nacional (LEITE LOPES, 2004).

Diante de fortes pressões, em $1^{\circ}$ de dezembro de 1935, Anísio Teixeira encaminhou carta a Pedro Ernesto solicitando a sua exoneração da então Secretaria Geral de Educação e Cultura. A exoneração foi aceita no dia seguinte, tendo Anísio Teixeira seu trabalho enaltecido pelo prefeito do Distrito Federal.

9 Decreto $n^{\circ} 19.941$ de 30 de abril de 1931-Dispõe sobre a instrução religiosa nos cursos primário, secundário e normal 
Em sua carta de exoneração, Anísio Teixeira escreveu:

Conservo em meio de toda confusão momentânea, as minhas convicções democráticas, as que me dirigiram e aumentaram todo o meu esforço, em quatro anos de trabalho e de lutas incessantes, pelo progresso educativo do Distrito Federal e reivindico mais uma vez, para essa obra que é do Distrito Federal e não somente minha, o seu caráter absolutamente republicano e constitucional e a sua intransigente imparcialidade democrática e doutrinária (ANÍSIO,1935 apud LEITE LOPES, 2004)

Exonerado, o citado ex-Secretário recebeu o apoio de colaboradores dos serviços de educação da capital brasileira. No mesmo dia em que ele encaminhou a sua carta de exoneração, Afrânio Peixoto e Roberto Marinho de Azevedo - da UDF, Antonio Carneiro Leão, Gustavo Lessa, entre outros, subscreveram o abaixo assinado:

Nós, abaixo firmados, colaboradores do Dr. Anísio Spínola Teixeira nos serviços de educação do Distrito Federal, onde prestou, em quatro anos, maiores benefícios à sua causa escolar do que qualquer outro brasileiro em sua existência, vimos firmar nossa surpresa ao ato que o afastou daquela administração.

Espontaneamente demissionários, temos a ombridade de declarar nossa inabalável convicção, hauridos em testemunho quotidiano, que o Dr. Anísio Teixeira se manteve alheio a qualquer ideologia política subversiva da 
ordem constitucional, exclusivamente voltado à cultura nacional, pela educação e só com a educação. (PEIXOTO et al. , 1935 apud FÁVERO e LOPES,2009)

Quando assumiu a Diretoria Geral de Instrução Pública do Distrito Federal, em 1931, Anísio Teixeira já começava a reestruturar o ensino na capital brasileira, e para tal envia ofício a Costa Ribeiro:

Designo-vos para fazerdes parte da Comissão que deverá estudar uma melhor distribuição dos serviços de ensino e administração no systema escolar do Distrito Federal.

A aludida comissão, que funcionará sob minha presidência, será também constituida pelos Srs. Dr. Eduardo Bastos Agostini-Diretor da Escola Souza Aguiar, Dr. José Paranhos Fontenelle-docente da Escola Normal e Raul Werneck Teixeira de Castro- chefe da secção interino

Apresento-vos a s minhas cordiaes saudações (fonte: acervo Costa Ribeiro -MAST)

Em março do ano seguinte Anísio Teixeira transformou a antiga Escola Normal do Distrito Federal em Instituto de Educação. O Instituto era composto por uma escola secundária $^{10}$, uma Escola de Professores em nível superior, e escolas de aplicação para as práticas docentes: pré-escola e escola primária. O Instituto de Educação do Distrito Federal "seria o centro

10 A escola secundária respeitava o modelo implementado pela reforma do Ministro Francisco Campos, em 1931. 
responsável pela formação e aperfeiçoamento dos profissionais que deveriam reger as classes de alunos da rede educacional da cidade, enquanto sua Escola de Professores constituiu-se na primeira tentativa, no Brasil, de formar os antigos professores primários em curso superior" (LOPES, FÁVERO e LOPES,2009).

Quando foi criada, a UDF incorporou o Instituto de Educação e a Escola de Professores passou a ser denominada de Escola de Educação. Teve então sua função ampliada, passando agora a formar tanto professores para a escola primária, como já fazia, como também promover a formação pedagógica de professores secundários (FAVERO e LOPES,2009).

Costa Ribeiro tornou-se professor de Física da Escola Secundária do Instituto de Educação, após concurso de títulos, em 1935, ano em que o referido Instituto foi incorporado à UDF.

As primeiras universidades brasileiras foram de fato criadas na década de 1930. Em 1934 foi criada a Universidade de São Paulo (USP) e em 1935 a UDF. A UDF teve como primeiro Reitor, o médico Afrânio Peixoto, que juntamente com Anísio Teixeira recrutou diretores e professores daquela instituição.

Natural de Lençóis, Bahia, Júlio Afrânio Peixoto nasceu em 17 de dezembro de 1876, filho de Francisco Peixoto e Virgínia Morais Peixoto. Diplomou-se na Faculdade de Medicina da Bahia em 1897. Foi catedrático de Medicina Pública na Faculdade Livre de Direito de Salvador em 1902. No ano seguinte mudouse para o Distrito Federal tornando-se inspetor sanitário da saúde pública. Em 1904 passou a exercer a função de diretor do Hospital Nacional de Alienados. Dois anos depois exerceu, interinamente, as Cadeiras de Higiene e Saúde e Medicina Legal na Faculdade de Medicina do Rio de Janeiro. Entre 1907 e 1911 
dirigiu o Serviço Médico Legal da Polícia. Eleito para a Academia Brasileira de Letras (ABL) em 1910 ocupou a cadeira antes pertencente a Euclides da Cunha. Em 1923 tornou-se presidente da ABL. Em 1915 Afrânio Peixoto assumiu a direção da Escola Normal e também se tornou catedrático da Faculdade de Direito do Rio de Janeiro. No ano seguinte assumiu o cargo de diretor da Instrução Pública do Distrito Federal. Entre 1924 e 1930 foi deputado federal pela Bahia. Afrânio Peixoto foi ainda membro da Academia de Ciências de Lisboa e do Instituto de Medicina de Madri. Faleceu no Rio de Janeiro em 1942 ( PEIXOTO, 2010).

Em Fávero e Lopes (2009) encontra-se a história da criação e estruturação da UDF. Idealizada por Anísio Teixeira, a UDF foi instituída por decreto ${ }^{11}$ de Pedro Ernesto Batista, quando interventor, em 4 de abril de 1935. No dia seguinte ao decreto de criação Afrânio Peixoto foi nomeado Reitor da nova Universidade.

Em maio, o Reitor Afrânio Peixoto foi a Europa para representar o Brasil na inauguração do Instituto Luso-Brasileiro de Arte e Cultura, em Portugal, e no Congresso Internacional de Educação realizado na Inglaterra. Durante sua ausência, Anísio Teixeira passou a acumular as funções de Secretario Geral de Educação e Cultura e Reitor interino. Afrânio Peixoto aproveitou o período em que esteve na Europa para convidar professores franceses para a UDF. Para esse fim foi auxiliado pelo professor George Dumas, da Universidade de Sorbonne. Esses professores chegaram ao Brasil no início de 1936.

11 Decreto no 5513. 
Em junho de 1935, Anísio Teixeira acumulando as funções de Secretário Geral de Educação e Cultura e Reitor interino, baixou as instruções $\mathrm{N}^{\circ} 1$ que organizavam as Escolas que compunham a Universidade, e que vigorariam enquanto não fossem decretados os estatutos da Instituição.

A UDF era composta por cinco Escolas: Escola de Educação, Escola de Ciências, Escola de Economia e Direito, Escola de Filosofia e Letras e Instituto de Artes. Além dessas, era também constituída por instituições complementares, sendo elas: Biblioteca Central de Educação, Escola-Rádio, Escola Secundária do Instituto de Educação, Escola Elementar do Instituto de Educação, Jardim de Infância do Instituto de Educação, Escola Secundária Técnica João Alfredo, Escola Elementar Experimental Barbara Ottoni e uma escola maternal experimental (a ser instalada).

As Escolas da UDF eram destinadas, principalmente, a formar professores para o ensino secundário, mas também organizada como centro de investigação e pesquisa. A Escola de Ciências era composta pelas seguintes seções: Ciências Matemáticas, Ciências Físicas e Ciências Naturais. Para atender a referida Escola foram criadas cinco Cadeiras para o ensino das disciplinas, sendo elas: Matemática; Física e Química-Física; Química Geral, Inorgânica e Orgânica; Biologia Geral e Zoologia; Botânica e a última composta por Mineralogia e Geologia. Cada Cadeira era regida por um professor que era auxiliado por assistente(s), ou como chamado(s) informalmente, professores assistentes, todos contratados inicialmente.

Durante três anos, tempo destinado à formação de professores secundários, o aluno deveria frequentar cursos de fundamentos, de conteúdo e de integração profissional. Os cursos de fundamentos compreendiam as matérias biologia e sociologia 
educacional como também desenho e belas artes. Os cursos de integração profissional compreendiam Estudos de Educação, Psicologia Educacional, Medidas Educativas, Organização e Programas da Escola Secundária, Filosofia da Educação e Prática do Ensino Secundário. Finalmente, o curso de conteúdo compreendia as matérias especificas do curso escolhido.

O candidato, que pretendesse ingressar na UDF, deveria escolher um dos cursos de conteúdo de cada Escola. Na Escola de Ciências, os cursos de conteúdos oferecidos eram: Curso de Professor de Matemática ${ }^{12}$, Curso de Professor de Física ${ }^{13}$, curso de Professor de Química ${ }^{14}$ e curso de Professor de História Natural ${ }^{15}$.

Para o ingresso, naquele ano, eram exigidos, além do curso secundário, exames vestibulares. Quem optasse por um dos cursos oferecidos, pela Escola de Ciências, havia um conteúdo específico para cada curso, assim quem fosse prestar vestibular para o curso de Matemática tinha como programa geral os temas: Complementos de Álgebra, Álgebra Superior, Noções de Geometria Descritiva, Elementos de Geometria Analítica e final-

12 Quem optasse por esse curso, deveria cursar também disciplinas de Física.

13 Devendo cursar também disciplinas de matemática e Química - Física.

14 Devendo cursar também disciplinas de Matemática e Física (com programa menor), além das disciplinas química geral, química inorgânica, química orgânica e química-física, inerentes ao curso

15 Devendo cursar também disciplinas de Matemática - com programa menor, além dos cursos gerais de Mineralogia e Geologia, Biologia Geral e Zoologia, Botânica. Dentro do curso de Historia Natural, quem optasse pela Mineralogia e Geologia faria curso especial de Mineralogia, Geologia e Física (com programa menor). Quem optasse por Zoologia ou Botânica faria curso especial de zoologia ou botânica, além de química (com programa menor) 
mente Física. O curso de Física tinha o mesmo programa geral de Matemática acrescido de Química Orgânica e, naturalmente, Física. O curso de Química tinha no programa Física, Química Inorgânica e Química Orgânica. E o curso de História Natural tinha o mesmo programa de Química acrescido de Mineralogia e Geologia bem como Zoologia e Botânica. Era previsto que se o candidato apresentasse certificado de aprovação nas disciplinas correspondentes ao curso escolhido em Escolas Superiores, ou equivalentes, estaria dispensado, a critério das bancas examinadoras, dos exames vestibulares.

Juntamente com Anísio Teixeira, Afrânio Peixoto começou a compor o quadro de Diretores das Escolas, ainda em 1935, sendo nomeados: Roberto Marinho de Azevedo - Diretor da Escola de Ciências, Hermes Lima - Diretor da Escola de Economia e Direito, Edgardo Castro Rebello - Diretor da Escola de Filosofia e Letras, Celso Octavio do Prado Kelly - Diretor do Instituto de Artes e Manoel Bergström Lourenço Filho - Diretor da Escola de Educação. Logo no seu primeiro ano de existência, a UDF, em especial a Escola de Ciências, contou com importantes nomes no seu quadro docente, tais como o físico alemão Bernhard Gross, do Instituto Nacional de Tecnologia, nomeado para professor da Cadeira de Física; Lélio Gama, da Escola Politécnica e do Observatório Nacional, nomeado para professor da Cadeira de Matemática; Lauro Travassos, do Instituto Oswaldo Cruz, nomeado para professor da Cadeira de Zoologia; Alberto José de Sampaio, do Museu Nacional, nomeado para professor da Cadeira de Botânica; Djalma Guimarães, do Serviço Geológico e Mineralógico, nomeado para professor da Cadeira de Mineralogia e Geologia e Alfredo Schaeffer, nomeado para professor da Cadeira de Química. Para assistentes 
das cadeiras foram contratados: Plínio Sussekind da Rocha Física, Herman Lent - Zoologia, Viktor Leinz - Mineralogia e Zoologia, Francisco Mendes de Oliveira Castro - Matemática, Carlos Viana Freire - Botânica e Durval Potyguara Esquerdo Curty - Química.

Merece destaque ainda, Gilberto Freire, nomeado para professor da Cadeira de Antropologia e Sociologia Geral, da Escola de Economia e Direito; Heitor Villa-Lobos, nomeado para professor da Cadeira de Música e Canto Orfeônico; Cândido Portinari, nomeado para professor da Cadeira de Pintura Mural e Lúcio Costa nomeado para professor da Cadeira de Arquitetura, todos os últimos citados pertencentes ao Instituto de Artes. Registra-se ainda a presença, no quadro docente, da poeta Cecília Meirelles e do historiador Sérgio Buarque de Holanda.

As inscrições para o vestibular foram abertas no dia 22 de junho, prevendo o início letivo para julho e término em março de 1936. As aulas iniciaram com um total de 106 alunos matriculados nos cursos lecionados na Escola de Ciências, 54 nos cursos oferecidos na Escola de Economia e Direito, 25 nos cursos lecionados na Escola de Filosofia e Letras, 77 nos cursos oferecidos no Instituto de Artes e 530 matriculados nos cursos oferecidos na Escola de Educação.

Anísio Teixeira e Afrânio Peixoto priorizaram na criação da UDF a estruturação do corpo docente e a organização dos cursos, assim a UDF congregava intelectuais de expressão no país como professores, mas não contava com uma sede ou um campus, que estavam nos planos dos dois citados dirigentes, mas não para pôr em prática naquele momento. A estrutura física da UDF era composta por instalações escolares já existentes e 
as construídas por Anísio Teixeira, onde se alocava suas Escolas. Um bom exemplo é a Escola de Economia e Direito, inicialmente alocada no Colégio Pedro II, transferindo-se depois para a Escola Rodrigues Alves, onde já funcionava a Escola de Filosofia e Letras e o Instituto de Artes e, finalmente, em 1938 transferida para a Escola José de Alencar. A reitoria funcionava no prédio do Instituto de Educação, onde funcionava também a Escola de Educação. As aulas da Escola de Ciências, incluindo laboratórios, eram ministradas em instituições de onde provinham seus professores, como o Instituto Manguinhos ${ }^{16}$, Escola Politécnica e Hospital do Distrito Federal.

Em dezembro de 1935, Anísio Teixeira, exonerado, foi substituído por Francisco Campos. Também foram exonerados, e presos, Afrânio Peixoto, Edgardo Castro Rabello, Hermes Lima, entre outros. Afrânio Peixoto foi substituído pelo vice-reitor e professor da Escola de Ciências, Miguel Osório de Almeida, até o inicio de 1936, quando em março Affonso Penna Júnior assumiu a reitoria até novembro de 1937. Em janeiro de 1938 assumiu como reitor Alceu Amoroso Lima, que permaneceu até setembro, quando assumiu o novo reitor, José Baeta Viana, respondendo até janeiro do ano seguinte.

O ano letivo de 1936, na UDF, iniciou com as conferências da Missão Universitária Francesa, composta por professores contratados por Afrânio Peixoto no ano anterior. Esses professores eram das mais diversas instituições francesas: Émile Bréchier, professor de História da Filosofia da Universidade de Paris; Etienne Souriou, professor de Filosofia do Liceu da Universidade D'aix-em-Provence e de Lyon; Eugene Albertine, professor de

16 Atual FIOCRUZ (Fundação Instituto Oswaldo Cruz) 
Civilização Romana no Collège de France, Jacques Perret, professor de Língua e Literatura na Universidade de Montpellier; Jean Bourciez, professor de Filologia Romana na Faculdade de Letras de Montpellier.

A UDF, já sendo dirigida pelo novo Reitor, Affonso Penna, ainda era alvo de críticas daqueles que eram contrários à sua criação, por não possuir uma sede. Affonso Penna em entrevista ao O Jornal em 1936 reconhece tal deficiência e sai em sua defesa lembrando que a Sorbonne, em seus primeiros anos era chamada de 'Domus Magistrorum Pauperrima - Casa Pobríssima de Mestres' (PINTO, FAVERO E LOPES, 2009). Austregésilo de Athayde publicou um artigo no Diário da Noite em defesa da UDF "traçando um paralelo entre essa Universidade e a centenária Universidade de Londres" (idem, ibdem) escrevendo: "há quem estranhe que se tenha fundado aqui uma universidade para quatro ou cinco dúzias de rapazes e que haja nela quase tantos professores quanto alunos matriculados"(idem, ibdem), e conclui: "o que importa para a organização de uma universidade é o espírito que ordena e preside ao seu nascimento." (ATHAYDE, 1936 apud idem, ibdem).

Em fevereiro de 1938 ocorreu a solenidade de formatura da primeira turma de professores da UDF, num total de 127 formandos.

Em 21 de maio do citado ano, o interventor Henrique Dodsworth juntamente com Paulo de Assis Ribeiro, Secretário Geral de Educação e Cultura do Distrito Federal publicaram decreto ${ }^{17}$ reorganizandoaUDF, descaracterizandoaUniversidade. As Escolas receberam a denominação de Faculdades, perdendo

17 6215, de 21 de maio de 1938. 
o seu caráter formador de professores secundários. O corpo docente passou a ser constituído por professores catedráticos, professores adjuntos e assistentes além do professor chefe de seção. Para a $5^{a}$ seção, composta pelo curso de Física, foram criadas duas Cadeiras: uma de Física Teórica e outra de Física Experimental (incluindo física-química). Oito meses depois, a UDF seria incorporada à Universidade do Brasil.

O conhecido geneticista brasileiro Oswaldo Frota-Pessoa graduou-se em História Natural na UDF, e nos apresenta a sua ligação com essa Universidade e as consequências para a sua carreira profissional:

Naquele tempo não havia muitas opções fora das carreiras clássicas: medicina, engenharia ou direito. $\mathrm{o}$ fato extraordinário foi a fundação da Universidade do Distrito Federal (UDF), que oferecia o curso de Historia Natural, entre outros. Isso ocorreu em 1935. Um belo dia, estava passando pela Cinelândia [bairro central do Rio], quando encontrei um colega do curso secundário, Newton Dias dos Santos, que me contou sobre a nova universidade. Corremos para fazer a matricula e isso mudou meu destino.

A UDF foi criada por Anísio Teixeira[...]. Anisio era grande inovador e tinha claro que era preciso mudar o ensino no país.

Na turma de Historia Natural, em que entrei - a primeira da nova universidade - éramos 18 estudantes. Havia um desejo de mudança, em direção ao que propagava o manifesto dos Pioneiros da Educação Nova, redigido por Fernando de Azevedo em 1932. 
Anísio Teixeira queria formar excelentes professores secundários, mas também pesquisadores que promovessem o avanço do conhecimento. Para formar o quadro docente da Universidade, ele fez questão de procurar os melhores cientistas da época. Foi assim que conseguiu atrair para nosso curso chefes de pesquisa como Lauro Travassos, Viktor Leinz e Herman Lent.

Nosso professor de botânica era Alberto Sampaio, chefe da divisão de Botânica do Museu Nacional. Como nunca tinha dado aulas, propôs em nosso primeiro encontro que estudássemos famílias de plantas pouco conhecidas no Rio

Sugeriu que cada equipe de alunos estudasse uma família, usando o herbário do museu. Lançamo-nos diretamente na pesquisa. No meu caso, publiquei com um colega, Alcides Lourenço Gomes, meu primeiro artigo cientifico antes mesmo de terminarmos a graduação:'As saxifagáceas na flora fluminense', em 1938, na revista da flora medicinal.

Comecei ensinando ciências logo que me formei e permaneci 20 anos como professor do estado.

No final da faculdade de medicina, que cursei simultaneamente à de historia natural, fui fazer o curso de aplicação do Instituto Oswaldo Cruz, que me introduziu a pesquisa biomédica. Conheci assim grandes pesquisadores, discípulos de Oswaldo Cruz. 
Minhas relações com a genética também resultaram da criação da Universidade do Distrito Federal. o professor Lauro Travassos, que nos ensinava zoologia, achou que precisávamos ter noções de genética, tema que ganhava importância crescente. Para introduzir-nos no assunto, convidou Gustavo Mendes de Oliveira Castro, pesquisador de Manguinhos, muito culto e atualizado. $\mathrm{Na}$ primeira aula ele distribuiu cópias do artigo original do [botânico austríaco Gregor] Mendel [1822-1884] para discussão nas aulas seguintes. Eu me empolguei de tal maneira que fui à Biblioteca Nacional fazer um levantamento histórico sobre a noção de hereditariedade na Antiguidade, e publiquei um artigo sobre o assunto em 1940 na Revista da flora medicinal. Publiquei também um artigo de divulgação sobre genética:'por que se parecem os filhos com os pais?' na revista vamos ler. E então veio meu primeiro trabalho sobre ensino: ' o conceito de espécie no curso colegial', que saiu na revista do Museu nacional em 1944. Como se vê, a genética estava me cercando por todos os lados e definindo os três caminhos (entrelaçados) que dominaram minha atividade: a pesquisa, a divulgação e o ensino.

Fui nomeado professor de escola pública em 1938, assim que me formei em historia natural. Foi um período excelente, pois adorava dar aulas. Alguns anos mais tarde estudei as drosófilas na região de Campos de Jordão [SP] e acabei identificando várias espécies novas. Em 1950, reuni esses dados para publicar 
minha tese de doutoramento. Quando retomei minhas atividades como professor secundário, surgiu o convite para ser assistente de biologia e genética na Universidade do Brasil. Foi então que coordenei meu primeiro grupo de pesquisas sobre sistemática das drosófilas. (COSTA,2004).

Em 1958, Oswaldo Pessoa passou a compor o grupo de pesquisa sobre genética da Universidade de São Paulo (USP).

Com referência ao físico Bernhard Gross no seu depoimento e artigo, encontra-se o relato de sua vinda para o Brasil e o papel desempenhado por ele na UDF. A primeira vez que Gross esteve no Brasil era ainda uma criança de oito anos de idade, veio a passeio com sua família em 1914 e na ocasião visitaram o Rio de Janeiro, São Paulo, Porto Alegre e Pelotas. Na visita, sua família fez novos amigos neste país. Em dezembro de 1932, na Alemanha diplomou-se no Instituto de Stuttgart como Technische Physiker ou Fisico Técnico, como relatado por ele mesmo ${ }^{18: " E r a ~ j u s t a-~}$ mente uma das grandes épocas da física alemã” em que ele foi aluno de Planck, de Schrödinger:

Assisti as aulas do Planck, que eram excelentes, mas não o esperado, porque era tudo preparado direitinho. Ele tinha os cinco volumes de física dele, e praticamente dava esses cinco volumes. Tinha alunos que sublinhavam aquilo que ele dava. No fim,

18 Tive a grande sorte de ter acesso ao diploma de Gross guardado em sua antiga sala no Instituto de Física de São Carlos, e que hoje é ocupada pelo professor Guilherme Leal Ferreira, que com grande simpatia concedeu-me tal oportunidade. 
o livro estava todo sublinhado. Eram por assim dizer, perfeitos, demais. Tinha aulas do Schrödinger, que eram excelentes, inspiravam [...] No tempo em que estudei, o equipamento todo era produzido na oficina do Instituto de Sttutgart. Aliás, não se podia comprar, com pequenas exceções. Por exemplo, não se compravam contadores. Quando começou o contador de ponta, o contador Geiger-Müller não se comprava, todo mundo tinha que fazer (GROSS, 1976).

Em 1932, Gross - ainda trabalhando na Escola de Engenharia na qual se diplomou-enviou o artigo raios cósmicos, traduzido para o português e publicado na Revista Brasileira de Engenharia, sobre as medidas de radiação cósmica. Tais medidas foram realizadas descendo-se um aparelho no lago de Constanza, na Alemanha, a uma profundidade de 250 metros e também enviando balões sonda a uma altitude de 18500 metros. "[...]Como soube mais tarde foi inicialmente considerado com alguma desconfiança por tratar de um assunto que naquele tempo pareceu esotérico." (GROSS, 2000), no Brasil.

Em junho de 1933, Gross chegou ao Rio de Janeiro. Sobre os motivos que o trouxeram ao Brasil ele apresenta: "Quando me formei, e vi que era muito difícil arranjar alguma coisa na Alemanha, achei que valia a pena arriscar e tentar a vida aqui" (Gross, 1976). Sobre as informações que tinha da possibilidade de continuar seu trabalho no Brasil, Gross responde: "No fundo eram realmente poucas. Sabia-se que o Brasil era um país que começava a se desenvolver industrialmente. Então, havia a ideia de que não podia deixar de ter possibilidade nesta área. Agora, informações diretas, precisas, não tive" (GROSS, 1976). 
Ao chegar à capital da república brasileira, Gross já tinha amigos e parentes. Entre estes amigos da família estava Francisco Venâncio Filho, professor do Instituto de Educação e autor de um livro de Física para escolas secundárias. Foi Venâncio que o apresentou à Escola Politécnica do Rio de Janeiro. Sobre o laboratório de Física da Escola Politécnica, Gross nos conta:

\begin{abstract}
O laboratório de física da escola dispunha de uma área relativamente ampla, com sala para trabalhos experimentais e realização de exercícios de física, uma coleção de equipamentos clássicos, e um anfiteatro próprio. No que se refere ao material, certamente tinha mais o caráter de um laboratório de ensino de uma escola secundaria avançada do que de uma escola superior. Mas, o que faz a Física é o homem e não o equipamento. $\mathrm{E}$ sob este aspecto, a Física da politécnica tinha caráter profissional (GROSS, 2000).
\end{abstract}

Sobre o ensino de Física na Politécnica, Gross nos apresenta:

O ensino de Física naquele tempo certamente era profissional, mas não podia deixar de ser influenciado pelo fato de que a Física na Politécnica era uma disciplina auxiliar, dadas nos primeiros anos, e não conduzindo ao desenvolvimento de projetos mais amplos ou trabalhos de pesquisas originais (GROSS, 2000).

Na Escola Politécnica Gross conheceu o catedrático de Física, Dulcídio Pereira, que tinha como assistentes os professores Costa Ribeiro e Eugênio Hime. Foi então convidado para dar 
palestra sobre raios cósmicos na Politécnica. Fez três palestras sobre as medidas e elas tiveram uma boa participação. A partir daí fez amizade com o corpo docente de Física da Politécnica. Em novembro fez palestra sobre o mesmo tema, que também teve uma boa participação, no Instituto de Tecnologia, que no ano seguinte se tornou Instituto Nacional de Tecnologia (INT). A palestra foi dada na nova sede do Instituto, que já tinha a maioria dos laboratórios montados.

No acervo de Costa Ribeiro encontra-se que, em dezembro de 1933, foi publicado na revista Cultura, Técnica e Ciência, uma publicação do Diretório Acadêmico da Escola Politécnica, o artigo de Gross Problemas especiais na pesquiza da radiação cósmica, traduzido por Costa Ribeiro.

No início de 1934 existia a Diretoria de Pesquisas Científicas que congregava o Instituto de Tecnologia, o Instituto de Meteorologia, o Laboratório Central do Departamento de Produção Mineral e o Instituto de Biologia Animal, institutos subordinados ao Ministério da Agricultura.

Realizavam-se, semanalmente, conferências técnicas sobre assuntos tratados nos laboratórios do Instituto. Gross foi convidado para participar de uma das conferências, em que descreveu seu trabalho sobre raios cósmicos. Sendo então contratado como assistente técnico.

O convite para trabalhar como assistente técnico partiu do professor Miguel Ozório de Almeida, fisiologista e diretor do Instituo de Biologia Animal, que funcionava nas dependências do Instituto de Tecnologia. O professor Miguel Ozório estava 
interessado na condutibilidade elétrica dos zeólitos ${ }^{19}$ e Gross foi trabalhar com o professor no tema. Assim, em 10 de janeiro de 1934 Gross foi contratado como assistente técnico do Instituto de Biologia Animal ${ }^{20}$, sendo o seu primeiro trabalho no Brasil.

Para iniciar os meus trabalhos dispunha de uma sala bastante ampla, com as necessárias ligações de força e água, e uma capela para química, mas de resto vazia. Não era difícil obter alguns moveis tipo padrão de serviço publico, e uma mesa de experiência, que mandei construir. $\mathrm{Na}$ falta de equipamento de medida, conseguiu-se obter por empréstimo, de varias fontes, um galvanômetro razoavelmente sensível, caixa de resistências e mesmo um eletrômetro de quadrante. (Gross, 2000)

[...]Eu precisava de uma fonte de tensão, compraram uma bateria de acumuladores de 500 volts [...] em 1934 [...] conseguiu-se comprar uns equipamentos bons, da fabrica Hartmann-Braun na Alemanha. Ai se conseguiu comprar resistências de cravelhas que se usava, galvanometros. [...] aí se começou a importar, comercialmente, a partir desse tempo, até a guerra, uma porção de equipamento que ainda hoje existe e que era de muito bom padrão, incluindo o chamado

19 Silicato alcalino (mineral) de composição variável e fortemente embebido em água (GROSS, 1934).

20 Tive a grande sorte de ter acesso ao contrato de Gross guardado em sua antiga sala no Instituto de Física de São Carlos, e que hoje é ocupada pelo professor Guilherme Leal Ferreira, que com grande simpatia concedeu-me tal oportunidade. 
"Pendulo de Helmholtz" que é um interruptor de pendulo que hoje naturalmente não se usa mais porque tem circuitos eletrônicos transistorizado. (GROSS, 1976)

Os resultados das pesquisas sobre zeólitos foram publicados nos Anais da Academia Brasileira de Ciências em 1934, e no periódico alemão Zeitschrift fuer Kristallographie.

Em abril do mesmo ano, após uma crise, a Diretoria de Pesquisa Científica foi suspensa e o Instituto de Tecnologia passou à subordinação do Ministério do Trabalho, Indústria e Comércio. Com este fato, o Instituto de Biologia Animal foi extinto bem como a diretoria científica. Gross foi então contratado para exercer o cargo de Físico do INT em julho do mesmo ano ${ }^{21}$ :

Também em 34, mais ou menos em março ou abril, apareceu o diretor do Instituto com um rapaz de uns vinte e dois ou vinte e três anos dizendo que queria trabalhar comigo como assistente. Era o Plínio Sussekind da Rocha. Ele era professor de fisica numa escola da prefeitura em marechal Hermes [...]. Ele tinha, como cedo se verificou, uma grande visão, uma visão muito geral. Achei que era interessante ele se familiarizar um pouco com eletricidade e com medidas. Então disse a ele: olha vamos fazer um circuito de ponte, fazer as medidas elétricas não muito difí-

21 Tive a grande sorte de ter acesso ao contrato de Gross guardado em sua antiga sala no Instituto de Física de São Carlos, e que hoje é ocupada pelo professor Guilherme Leal Ferreira, que com grande simpatia concedeu-me tal oportunidade. 
ceis; e também comecei a dar uma espécie de curso particular sobre circuitos: oscilações em circuitos elétricos, que sempre era um dos assuntos de que mais gostava.vi logo que ele era extremamente inteligente e também com ele tive relações ótimas de colegas e pessoais (GROSS, 1976).

Ainda em 1934 a companhia telefônica LIGHT encomendou estudos ao INT:

Naquele tempo a Light estava interessada em saber a resistência do isolamento dos cabos telefônicos, que ela usava. Então, eu, ou melhor, nós começamos a medir. Aí estes fios apresentaram um fenômeno que sempre me tinha fascinado, já na Alemanha, além de raios cósmicos. Era o que se chama a absorção dielétrica.com a instalação bastante crua começava-se a medir a absorção dielétrica. À medida que se progredia, também começavase os estudos da parte teórica e daí saiu uma série de trabalhos, que, de certo modo, ainda hoje continua, porque ainda se trata de um assunto que é tão atual como naquele tempo. (GROSS, 1976)

Na ocasião começou também a chegar o aparelhamento de precisão para medidas elétricas em corrente contínua e alternada, que se tinha encomendado, o que tornou possível a realização de uma serie de trabalhos teóricos e experimentais sobre absorção dielétrica e descarga de capacitores. Os primeiros trabalhos foram feitos em colaboração com Plinio Sussekind Rocha. (GROSS, 2000) 
No ano seguinte Gross passou a compor o quadro da UDF: "[...] no começo de 1935, uma tarde recebi um telefonema, depois uma visita de Roberto Marinho de Azevedo, em que ele me convidou para ser professor de Física na Universidade do Distrito Federal. Aí comecei a lecionar [...]"(GROSS, 1976). "Como primeiro assistente tive Plínio Sussekind da Rocha que, como mencionei acima, já estava trabalhando comigo no Instituto de Tecnologia" (GROSS, 2000).

Coube ao físico alemão organizar a grade curricular da UDF, "o curso de Física Geral era de 5 semestres - Mecânica, Termodinâmica, Eletricidade e Magnetismo, Ótica, e Física Atômica. A matéria correspondia àquilo que naquele tempo se dava em um curso de física geral na Alemanha" (GROSS, 2000).

Gross também nos apresenta um pequeno perfil do corpo discente da primeira turma:

Bom, a primeira turma da Universidade do Distrito Federal tinha uma serie de alunos muito bons. Um era o Gabriel Fialho de Almeida [...] ele tinha se formado em engenharia. [...] tinha o Dodsworth que era filho do ex-prefeito do Rio. Tinha o Weimar Pena. [...] Tinha dois Guedes: um era Francisco [...] se não me engano, um, depois, se tornou diretor do Instituto Brasileiro do Café. Tinha uma moça Ivone. [...] era uma turma de mais ou menos 12, acho que eram 15. A segunda turma era menor. Eu me lembro de um que era Salo Brandt que depois foi prefeito de Niterói ou pelo menos de algum Município do Estado do Rio (GROSS, 1976). 
Sobre o local onde ministrava suas aulas, Gross informa que "As aulas de Física foram dadas no anfiteatro do Instituto de Tecnologia; outras matérias foram dadas em uma escola da Prefeitura situada na Praça de Caxias (hoje Largo do Machado)" (GROSS, 2000).

Findado o primeiro semestre letivo de existência, em maio de 1936 Costa Ribeiro passou a compor o quadro de assistentes da UDF. Foi inicialmente contratado como assistente de Física na Escola de Ciências. Seu contrato ${ }^{22}$ teria a duração de um ano letivo ${ }^{23}$ e sua carga horária era de 12 horas semanais, que deveria ser cumprida de acordo com o organizado pelo diretor da referida Escola, naquele momento o ainda primeiro diretor, Roberto Marinho. Após nove meses da sua assinatura e de iniciar suas atividades, seu contrato foi renovado por igual período firmado inicialmente.

Sobre a ida de Costa Ribeiro para a UDF, Gross indica: “[...] veio também como assistente, o professor Costa Ribeiro que iniciou as primeiras aulas práticas dadas, pelo que me lembro, no laboratório de Física da Escola Politécnica" (GROSS, 2000). "começou-se também as compras de equipamentos. Em particular, o professor Costa Ribeiro que estava sempre muito interessado em Ótica. Eu me lembro que no último ano, em 1937 [...] compramos um banco Ótico mais completo da LEITZ da Alemanha..." (GROSS, 1976).

22 Conforme consta em seu acervo no MAST, este contrato foi assinado pelo Reitor, Afonso Pena Junior. A contratação de professores e funcionários para a UDF deveria ser autorizada pelo Prefeito do Distrito Federal, já que esta estava diretamente subordinada a esta prefeitura.

23 De 15 de maio de 1936 a 30 de abril de 1937. 
Durante seus primeiros três anos de existência, o curso de Física da UDF teve como professores: Gross, Sussekind e Costa Ribeiro.

Já quase findando o ano de 1937, mais precisamente no dia 10 de novembro, o Presidente Getúlio Vargas dissolveu a Câmara dos Deputados, o Senado Federal, as Assembléias Legislativas dos Estados e as Câmaras Municipais e ainda determinou a prisão de adversários políticos e impôs uma constituição autoritária ao país, iniciando um período conhecido como Estado Novo ${ }^{24}$. Essa constituição permitia ao Presidente governar por decretos-leis (leis impostas). No mesmo dia e ano, a constituição de 1934 teve artigos suprimidos ou modificados. Uma destas modificações se referia ao artigo 172, que constava:

É vedada a acumulação de cargos públicos remunerados da União, dos Estados e dos Municípios.

$\S 1^{0}$ - Excetuam-se os cargos do magistério e técnico-científicos, que poderão ser exercidos cumulativamente, ainda que por funcionário administrativo, desde que haja compatibilidade dos horários de serviço.

Com a nova constituição autoritária de 1937, o artigo 172 transformou-se no artigo 159 mantendo o mesmo texto e suprimindo todos os seus parágrafos. 
Ainda no mesmo mês, foi editado o decreto-lei ${ }^{25}$ que dispunha sobre a acumulação de funções e cargos públicos remunerados. Seu texto era mais específico que o artigo 159 e instruía sobre providências a serem tomadas por funcionários públicos que incidisse sobre alguns de seus artigos:

Art.1ํ É vedada a acumulação de funções ou cargos públicos remunerados da União, dos Estados ou Municípios, bem como de uma e outra dessas entidades, qualquer que seja a forma da remuneração.

Art. $2^{\circ}$ O funcionário ou empregado civil, ou o militar, que na data desta lei estiver acumulando funções ou cargos públicos remunerados, deverá optar dentro de trinta dias, a partir da data da publicação desta lei, por um só cargo ou função.

Neste mesmo decreto-lei são apresentados dois artigos que tratam da nomeação por comissão e remuneração acumuladas:

Art. $7^{\circ} 0$ funcionário civil, ou o militar, que aceitar a nomeação para exercer cargo em comissão com vencimentos fixados em lei, perderá, enquanto durar esse exercício, os proventos do cargo efetivo, mas a este voltará desde que cesse a comissão.

Parágrafo único. Não poderá, porém, o funcionário federal, ou o militar, aceitar nomeação para cargo estadual ou municipal dessa natureza sem prévia e expressa licença do Presidente da Republica.

25 Decreto lei n²4, de 29 de novembro de 1937. 
Art. $8^{\circ}$ Quando os vencimentos do cargo efetivo forem superiores aos do cargo em comissão, o funcionário poderá optar por aqueles.

Ao funcionário civil, ou ao militar no exercício das funções de interventor federal, ou, por nomeação do Presidente da República, de outras funções de governo ou de administração em qualquer parte do território nacional, será igualmente permitido optar pelos vencimentos do seu próprio cargo ou posto.

Este decreto tornava mais flexível a administração de Getúlio Vargas, já que era permitido a ele e a seus ministros comissionarem funcionários, o que não estava previsto no artigo 159 da constituição do Estado Novo.

Dessa forma, o artigo 159 e o decreto-lei n 24 atingiram não somente o funcionalismo público geral, mas diretamente a Escola de Ciências, a começar pela saída de seu diretor, Roberto Marinho, que era Catedrático da Escola Politécnica, e que antes de afastar-se do referido cargo deixou registrado nos assentamentos ${ }^{26}$ daquela Universidade, cujo destinatário era o professor Joaquim da Costa Ribeiro a mensagem:

Sr. Professor:

Ao deixar a Escola de Ciências em obediência ao decreto-lei relativo às acumulações remuneradas,cumpre-mevosagradecerosserviços que desde a fundação da Universidade vindes

26 Oficio nำ 134-EC, da Escola de Ciências da Universidade do Distrito Federal de 31 de dezembro de 1937. 
prestando ao ensino da nossa Escola, com a vossa competência e dedicação, elevando-o a nível não comum no nosso país. Vencemos juntos as primeiras dificuldades. Consegui para a Escola de Ciências o fator essencial a um ensino eficiente: o professor idôneo,e, também, o aparelhamento indispensável. Falta-nos ainda o edifício que as circunstâncias não nos permitiram realizar. Com os votos de felicidade no novo ano, e os protestos de muita estima e consideração, envio-vos as minhas despedidas, pedindo dispor de mim como de um amigo obrigado (fonte: acervo Costa Ribeiro-MAST).

Em 1938 registrou-se a presença de Luiz Freire como diretor da então Faculdade de Ciências da UDF $^{27}$. Sobre Freire, Costa Ribeiro escreveu:

Cabe [...] a Luiz Freire, professor de Física da Escola de Engenharia de Pernambuco, o mérito excepcional de manter naquele centro de estudos do Norte do país um alto nível de ensino da física e da matemática e ao mesmo tempo, a rara perspicácia de descobrir autenticas vocações para a pesquisa nesses domínios, encaminhando aos centros do Rio de Janeiro e São Paulo jovens excepcionalmente bem dotados para a investigação, bastando citar entre eles os nomes de Mário Schemberg, J. Leite Lopes, L. Nachbin e outros (COSTA RIBEIRO, 1994).

27 Diário Oficial da União, 25 de outubro de 1938. 
O físico José Leite Lopes nos fala sobre sua relação com Luiz Freire:

Conheci-o no ano de 1936, quando ingressei na Escola de Engenharia de Pernambuco com a intenção de tornar-me químico industrial. As primeiras aulas de Física, no gabinete da velha Escola, proferidas por Luiz Freire tiveram para mim a força de uma revelação.

Com a atenção presa no que dizia e escrevia no quadro negro, começávamos a descobrir a Física [...] imediatamente senti, que o meu caminho não era o de químico industrial e orientei os meus passos, sob sua influência [...]. (LEITE LOPES, 2004)

Leite Lopes então se dirigiu ao Distrito Federal e ingressou na Faculdade Nacional de Filosofia da Universidade do Brasil, obtendo o título de Bacharel em Física e tornando-se um importante físico brasileiro.

Sobre a passagem de Luiz Freire na UDF, Leite Lopes descreve:

Em 1938, Luiz Freire foi convidado para ser professor na Faculdade de Ciências da então florescente Universidade do Distrito Federal. Ali esteve trabalhando durante alguns meses, mas quando se aprontou para mudarse definitivamente do Recife para a Capital Federal, ao solicitar ajuda para a viagem da família. Foi-lhe dito pelo órgão burocrático apropriado, frieza característica, que a ajuda só era possível para professores estrangeiros. De nada valeu a intervenção das autoridades universitárias, dos seus amigos, perplexos 
diante da discriminação. Permaneceu, assim, Freire no Recife, não sem antes haver dirigido veemente protesto às autoridades da República (LEITE LOPES, 2004).

Leite Lopes nos apresenta ainda a materialização da grande obra de Luiz Freire na capital pernambucana:

Sempre em contato com os pesquisadores do Rio de Janeiro e São Paulo, foi convocado por Álvaro Alberto para integrar o grupo que estruturou e criou o Conselho Nacional de Pesquisas. Foi membro desse Conselho desde a fundação em 1951 até a data do seu falecimento. Com o pensamento sempre voltado para o desenvolvimento cientifico da nossa terra, viu, finalmente, nesses órgãos, a fonte de ajuda que ate então lhe faltava. Fundou, assim, na Universidade do Recife, com o apoio do Conselho Nacional de Pesquisa, o Instituto de Física e Matemática. Do qual foi Diretor. Era o coroamento da sua obra, pois sabia que somente poderia reter no Recife os jovens que formava para a pesquisa cientifica, se lhe pudesse oferecer uma instituição e um ambiente adequado. (LEITE LOPES, 2004).

Após a apresentação sobre Freire, retornemos à saída dos professores da UDF devido ao Estado Novo. Além do diretor Roberto Marinho, a Escola de Ciências, e em especial a seção de ciências Físicas, perdeu o professor e organizador do curso, Bernhard Gross, que optou pelo Instituto Nacional de Tecnologia. Plínio Sussekind também teve que deixar a docência na UDF, optando por permanecer no cargo de professor de Física de escola da prefeitura, onde era professor concursado. 
Com o professor Costa Ribeiro não foi diferente, também foi obrigado a optar por uma das escolas que lecionava. Naquele momento era professor de quatro instituições de ensino: professor de Física e Química de Escola Técnica Secundária da Prefeitura do Distrito Federal, assistente da Cadeira de Física da Escola Politécnica, professor de Física da Escola Secundária do Instituto de Educação, professor assistente de Física da UDF, além do cargo de auxiliar técnico. Costa Ribeiro permaneceu como professor da Escola Secundária do Instituto de Educação ${ }^{28}$.

Assim, dos três professores do referido curso, somente Costa Ribeiro permaneceu, cumprindo o seu contrato.

No quarto dia de 1938, Costa Ribeiro foi nomeado chefe de gabinete de Paulo de Assis Ribeiro, Secretário Geral de Educação e Cultura do Distrito Federal. Em março, o secretário de educação precisou afastar-se de suas atividades por um período de aproximadamente dois meses. Costa Ribeiro então foi nomeado pelo prefeito para responder por este expediente, tornando-se neste período o Secretário Geral do referido órgão distrital ${ }^{29}$. Ao reassumir a secretaria, Paulo de Assis expediu ofício de agradecimentos a Costa Ribeiro:

Ao reassumir esta Secretaria, quero deixar consignados o meu reconhecimento e a minha profunda satisfação pela incansavel dedicação e alta competência com que dirigistes durante a minha ausência.

28 Diário Oficial da União, 7 de outubro de 1947.

29 Costa Ribeiro respondeu por tal expediente de 24 de março a 10 de maio de 1938. 
Foi árdua a tarefa com que vos incubiu, de responder pelo expediente da secretaria numa fase de reorganização, na qual medidas de grande alcance, quer técnico quer administrativo, precisaram ser tomadas, sobrelevando-se o preenchimento de vagas de professores, tanto no instituto de educação, como no Ensino Técnico Secundário. A tudo acudistes com o maior acerto e o mais elevado critério, dando ao cargo que transitoriamente ocupastes, o melhor do vosso esforço e da vossa reconhecida capacidade.

Como chefe e como amigo agradeço-vos os grandes serviços que prestastes a esta secretaria e a mim próprio, substituindo- me, além do mais, com a constante preocupação de não permitir a menor solução de continuidade entre a vossa e a minha administração (fonte: acervo Costa Ribeiro - MAST).

Costa Ribeiro respondeu como chefe de gabinete da Secretaria até julho daquele ano, quando pediu para ser dispensado da função, já que havia sido comissionado para outro cargo.

Foi designado no referido mês, pelo prefeito do Distrito Federal, o interventor Henrique de Toledo Dodsworth para exercer em comissão, o cargo de professor catedrático da Cadeira de Física Experimental da UDF, em que tomou posse sem interrupção de suas atividades docentes ${ }^{30}$. Exatos trinta e um dias depois, foi designado professor-chefe da $5^{\mathrm{a}}$ seção pelo Reitor Alceu Amoroso

30 Conforme documento exarado pelo Prefeito do Distrito Federal. Consta em seu acervo pessoal no MAST. 
Lima. Para a Cadeira de Física Teórica foi nomeado Luiz C. Dodsworth Martins ${ }^{31}$, como Gross nos apresentou, filho do interventor do Distrito Federal. Costa Ribeiro exerceu suas atividades na UDF até essa ser incorporada à Universidade do Brasil (UB).

\section{Universidade do Brasil e a Continuação da Atividade Docente}

A Universidade do Brasil (UB) foi criada em 1937, meses antes do Estado Novo. Foi aprovada pelo poder legislativo e sancionada por Getúlio Vargas. A UB teria a sua sede no Distrito Federal e conforme a lei ${ }^{32}$ que a criou seria composta por quinze estabelecimentos de ensino, a saber: Faculdade Nacional de Filosofia, Ciências e Letras; Faculdade Nacional de Educação; Escola Nacional de Engenharia; Escola Nacional de Minas e Metalurgia; Escola Nacional de Química; Faculdade Nacional de Medicina; Faculdade Nacional de Odontologia; Faculdade Nacional de Farmácia; Faculdade Nacional de Direito; Faculdade Nacional de Política e Economia; Escola Nacional de Agronomia; Escola Nacional de Veterinária; Escola Nacional de Arquitetura; Escola Nacional de Belas Artes e Escola Nacional de Música.

Ainda como previsto na sua lei de criação, a UB passou a incorporar instituições acadêmicas já existentes e estas receberam suas denominações correspondentes. A Escola Politécnica passou a chamar-se Escola Nacional de Engenharia, a Escola de Minas - Escola Nacional de Minas e Metalurgia, a Faculdade

31 Diário Oficial da União, 25 de outubro de 1938.

32 Lei nำ452 de 5 de julho de 1937. 
de Medicina - Faculdade Nacional de Medicina, a Faculdade de Odontologia - Faculdade Nacional de Odontologia, a Faculdade de Farmácia - Faculdade Nacional de Farmácia, a Faculdade de Direito - Faculdade Nacional de Direito e o Instituto Nacional de Música - Escola Nacional de Música. Apesar de prevista a construção da cidade universitária, o que aconteceria décadas depois, as sedes dessas Faculdades e Escolas nacionais se mantiveram no mesmo local de seu funcionamento, válido o mesmo para a agora Escola Nacional de Minas e Metalurgia que continuaria com a sua sede em Ouro Preto e que já pertencia à Universidade do Rio de janeiro.

Como uma característica sua, a UB passou a incorporar instituições já existentes. Os primeiros cursos incorporados a esta "universidade nacional" foram os cursos integrantes da Universidade do Rio de Janeiro. Assim a Universidade do Rio de Janeiro deixou de existir. As outras faculdades nacionais previstas ficaram no papel até 1939, quando mais uma vez ocorreria novas incorporações à UB por decreto lei. Chama a atenção no texto da lei que criou a UB o capítulo VI, Disposições Gerais:

Art. 30. Os professores e os alunos da Universidade do Brasil não poderão comparecer aos trabalhos escolares ou a quaisquer solenidades universitárias, com uniforme ou emblema de partidos políticos.

Tal artigo reflete o momento político da época. Em janeiro de 1939 um decreto-lei ${ }^{33}$ transferiu quase todos os estabelecimentos de ensino que compunham a UDF para a UB. A Faculdade

33 Decreto-lei n 1063 de 20 de janeiro de 1939 
de Filosofia e Letras, a Faculdade de Ciências, a Faculdade de Economia e Política e a Faculdade de Educação foram incorporados à Faculdade Nacional de Filosofia, Ciências e Letras da UB. Os cursos do Instituto de Artes foram incorporados à Escola Nacional de Belas Artes eà Escola Nacional de Música. No entanto alguns cursos e instituições que faziam parte da UDF não foram incorporados, como foi o caso do Instituto de Educação, o curso de formação de professores primários, o curso de orientadores de ensino primário, o curso de administradores escolares e os cursos de aperfeiçoamento da Faculdade de Educação. Os alunos que estavam regularmente matriculados nos cursos transferidos puderam continuar seus estudos na UB.

Quando foi criada a Faculdade Nacional de Filosofia, Ciências e Letras em 1937, seu texto era muito abrangente, não especificava, por exemplo, quais os cursos que fariam parte da mesma. Versava de maneira muito simples que a Faculdade ministraria os cursos de filosofia, de ciências e de letras. A existência de fato de cursos que comporiam esta Faculdade se deu a partir da transferência dos cursos da agora antiga UDF para a UB, que até então existia no papel, e em consequência disso fez com que fosse necessário organizá-la ${ }^{34} \mathrm{em}$ função da estrutura existente, ou seja, dos cursos da UDF. Passou então de Faculdade Nacional de Filosofia, Ciências e Letras à denominação de Faculdade Nacional de Filosofia (FNFi). Era composta por quatro seções: Seção de Filosofia, Seção de Ciências, Seção de Letras, Seção de Pedagogia e ainda uma seção especial de didática.

A seção de ciências era composta por seis cursos: Matemática, Física, Química, História Natural, Geografia e História como um único curso, e o sexto curso, o de Ciências Sociais, todos criados

34 Esta organização veio pelo decreto-lei no 1190 de 4 de abril de 1939. 
na UDF por Anísio Teixeira. Todos os cursos pertencentes agora a UB tinham uma duração de três anos e ao final destes eram conferidos aos concludentes os diplomas de bacharel. Portanto, para se obter o diploma de bacharel em Física deveria se cumprir as seguintes disciplinas por séries, sendo que cada série correspondia a um ano de curso: Primeira série - Análise Matemática, Geometria Analítica e Projetiva, Física Geral e Experimental; Segunda série - Análise Matemática, Geometria Descritiva e Complementos de Geometria, Mecânica Racional, Física Geral e Experimental; Terceira série - Análise Superior, Física Superior, Física Matemática, Física Teórica.

Para se obter o diploma de licenciado, o bacharel deveria concluir o curso de didática, pertencente à seção especial de didática, que tinha a duração de um ano e que era composta pelas disciplinas: Didática Geral, Didática Especial, Psicologia Educacional, Administração Escolar, Fundamentos Biológicos da Educação e Fundamentos Sociológicos da Educação.

Para quase todas as disciplinas ensinadas na FNFi foi criada uma Cadeira, sendo criadas na Faculdade 45 cátedras. Em alguns casos, duas ou três disciplinas ficaram pertencentes a uma única cátedra, como foi o caso da décima Cadeira ${ }^{35}$ que era composta pelas disciplinas Mecânica Racional, Mecânica Celeste e Física Matemática ou o caso da décima segunda Cadeira que agrupava Física Teórica e Física Superior. Cada Cadeira ficava a cargo de um professor catedrático. Ao catedrático caberia elaborar o programa da disciplina da cadeira a qual pertencia. 0 catedrático poderia ainda dispor de um ou mais assistentes, que seria indicado(s) por ele.

35 As cátedras eram identificadas também pelos números. 
Gustavo Capanema, Ministro da Educação, queria para o quadro docente da FNFi professores estrangeiros, e para isso manteve contato, inclusive com o professor George Dumas, o mesmo que havia auxiliado Afrânio Peixoto, efetivamente, na contratação de professores franceses que se deu através de contatos com a embaixada francesa (SILVA, 2002). Da França vieram diversos professores para as áreas das Ciências Humanas e Linguística. Para a Matemática, vieram italianos. Em junho de 1939 Vargas autorizou a contratação de quinze professores estrangeiros para a FNFi (SILVA, 2002). "A chegada dos matemáticos italianos no Rio de Janeiro concretizou-se pelos canais oficiais [...] pelos contatos da embaixada brasileira diretamente com a embaixada italiana" (SILVA, 2002), como comprova a carta que o embaixador italiano Ugo Sola enviou a Gustavo Capanema:

Vossa Excelência deu-me a honra de pedir em nome do Governo Brasileiro, ao Governo da Itália a designação para a Faculdade de Filosofia na Universidade Federal [...] de professores italianos destinados a reger as cadeiras: a) língua e literatura italiana; análise matemática e superior, c) mecânica racional; d) física teórica e superior; e) físico-quúmica e química superior; f) geometria superior; g) física experimental [...]. Os pedidos de docentes italianos feitos por Vossa Excelência e que honram altamente a ciência e a literatura italiana, foram imediatamente transmitidos ao Real Governo que, sem demora [...] teria providenciado as relativas designações (FÁVERO, 1989, apud SILVA, 2002). 
Os italianos que vieram para a matemática foram Gabrielle Mammana e Achille Bassi (SILVA, 2002). Para a Cadeira de Física Teórica e Física Matemática da FNFi veio o também italiano Luigi Sobrero, que era professor de Fisica Matemática na Universidade de Roma $^{36}$ (Sobrero, 1942)

Pesa sobre a indicação de professores italianos pelo próprio Governo Italiano, o fato de alguns serem divulgadores de ideias fascistas. Quando o Brasil, em 1942, entrou na Segunda Guerra Mundial, em maio desse ano o contrato dos professores italianos foram rescindidos, retornando à Itália Luigi Sobrero e Gabrielle Mammana, Achille Bassi permaneceu no Brasil com sua família (SILVA, 2002).

Em julho de 1939 Costa Ribeiro foi comissionado pelo Presidente da República no cargo de professor catedrático de Física Geral e Experimental, décima primeira cátedra, da recém reorganizada Faculdade. Ao final deste ano foi nomeado para exercer interinamente o referido cargo, e nesta condição permaneceu até 1945. Como previsto, coube a ele elaborar o conteúdo programático de sua cátedra. O conteúdo elaborado por Costa Ribeiro contemplava os dois primeiros anos do curso de Física, período em que era ministrada essa disciplina. Física Geral e Experimental fazia parte também das disciplinas que compunham os cursos de matemática e química. Esta era ministrada na primeira e segunda séries para Matemática, e na primeira série para Química.

A estrutura física da FNFi era a mesma da UDF, sendo a Faculdade alocada entre 1939 e 1942 na antiga escola José de Alencar, no largo do Machado (SILVA, 2002).

36 Luigi Sobrero foi contratado para UB também em 1939. 


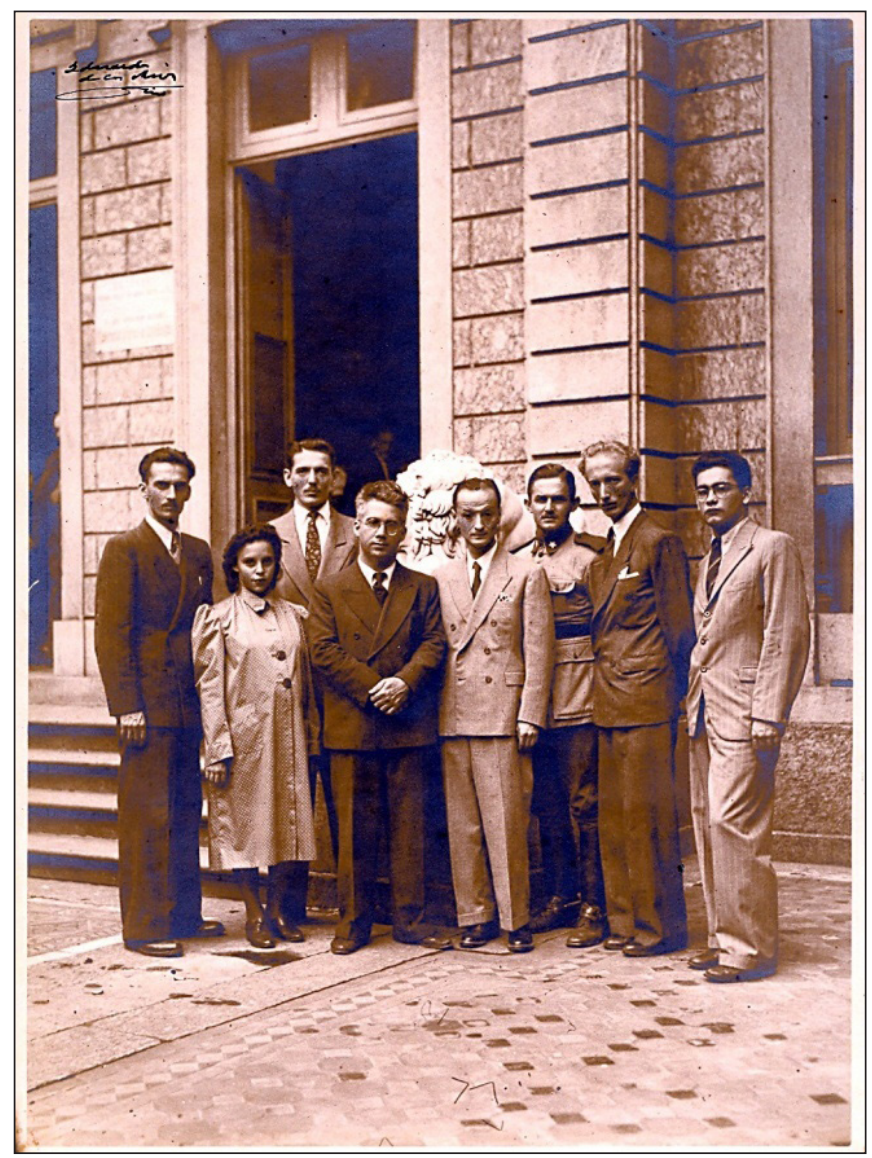

Figura2: Faculdade Nacional de Filosofia, no Largo do Machado (RJ), no início da década de 1940; da esq. para dir., Alcântara Gomes, Elisa Frota-Pessoa, Jayme Tiomno, Joaquim da Costa Ribeiro, Luigi Sobrero, Leopoldo Nachbin, José Leite Lopes e Maurício Peixoto

Fonte: acervo Leopoldo Nachbin - MAST). 
Com o Brasil fazendo parte dos Aliados na Segunda Guerra Mundial, uma solução providencial para que a FNFi, enfim, tivesse uma sede foi quando a Casa d'Itália fora "[...] confiscada pelo Governo em 1942 após a declaração de guerra à Italia" (Gross, 2000).

Jayme Tiomno relembra que Costa Ribeiro ficou encarregado de fazer a inspeção do prédio da Casa d'Itália:

Quando a Faculdade foi transferida do Largo do Machado para a Casa d'Itália, o Reitor encarregou o Costa Ribeiro de fazer um levantamento do prédio e ele me chamou. Nós fomos as duas primeiras pessoas a entrarmos no prédio. Examinamos sala por sala. Costa Ribeiro fez um relatório ao diretor e, naturalmente, escolheu a melhor sala para o laboratório de Física.

Sugerimos, também, a distribuição das seções, de outros laboratórios, de salas de aula (JAYME TIOMNO,1992).

Encontrei na Revista do Serviço Público, publicada em 1945 pelo Departamento Administrativo do Serviço Público do Governo Federal, uma reportagem do jornalista Adalberto Mario Ribeiro, que apresenta a FNFi, com sede

[...] instalada na Antiga Casa d'Itália.

O novo órgão da Universidade do Brasil ocupa nesse edifício quatro andares: o $2 .^{\circ}, 04 .^{\circ}, 05 .^{\circ}$ e o $6^{\circ}$, mantendo ainda algumas seções na sede primitiva, na Escola José de Alencar, no largo do Machado.

No 3. andar funciona uma dependência do ministério da justiça: o Juizo de Menores. 
Quando subíamos ao 4. ${ }^{\circ}$ andar, onde deveríamos falar ao diretor da Faculdade, o elevador deixou no $3 .^{\circ}$ três senhoras pobres e dois meninos, gente sofredora que no Juizo de Menores ia procurar, com certeza, alguma assistência social, amparo, por algum tempo, para os filhos carecedores de proteção (RIBEIRO, 1945).

O Departamento de Física funcionava no $6^{\circ}$ andar.

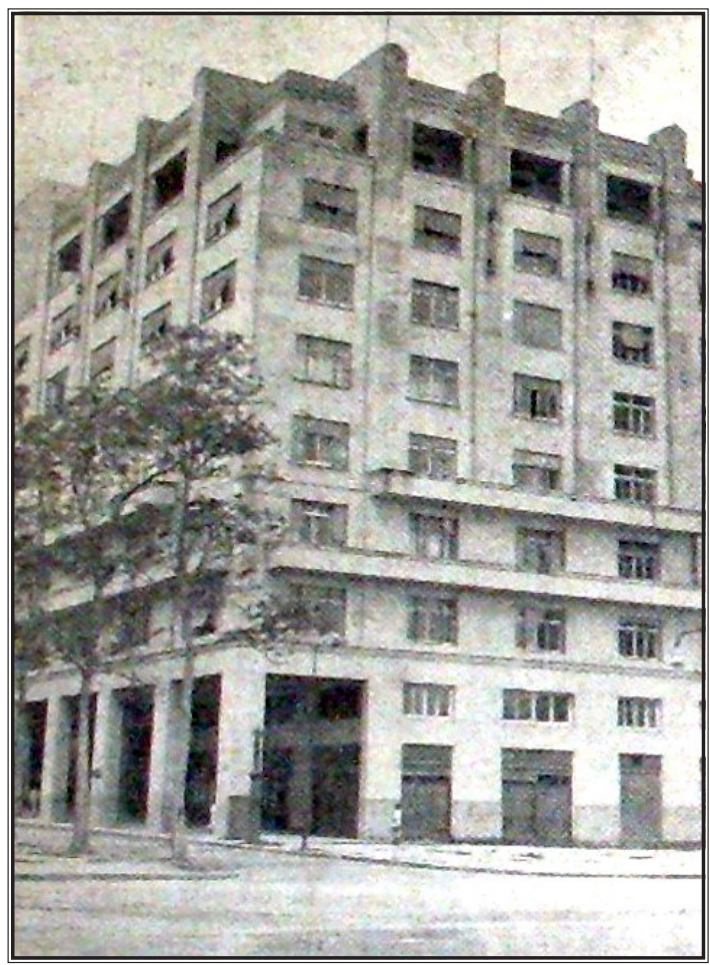

Figura 3: A sede da Faculdade Nacional de Filosofia antiga Casa d'Itália ${ }^{37}$.

37 Fonte: Revista do Serviço Público, publicada em 1945. 
$\mathrm{Na}$ referida reportagem, San Tiago Dantas, diretor da Faculdade, apresenta as condições dos laboratórios: “[...] ainda não contamos com o equipamento material indispensável para a realização de grandes trabalhos de pesquisa e a ministração de certos ramos muito especializados no ensino" (RIBEIRO, 1945).

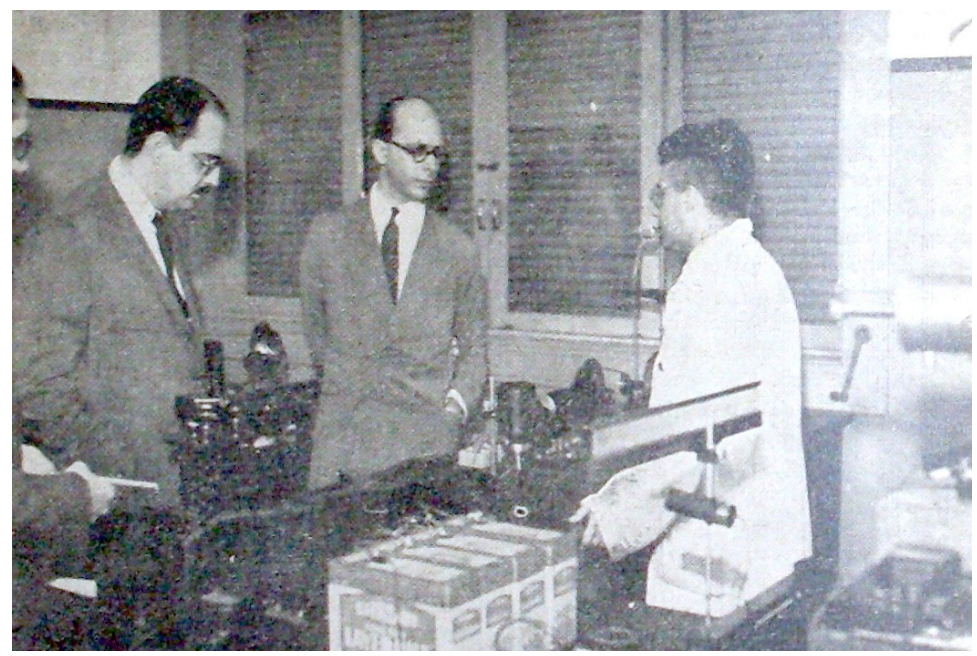

Figura 4: Laboratório de Física Experimental do Prof. Costa Ribeiro

Fonte: revista do serviço público, 1945

Em entrevista concedida a Adalberto Mário Ribeiro, Costa Ribeiro corrobora com a informação dada pelo diretor da FNFi. Quando o jornalista dirige a seguinte pergunta, "mas a realização de pesquisas originais não exige sempre a mobilização de consideráveis recursos e o aparelhamento de grandes e custosos laboratórios?", Costa Ribeiro responde quase que como um desabafo: 
A história mostra-nos que no desenvolvimento das ciências o fator humano desempenha, em geral, um papel muito mais importante do que os recursos materiais disponíveis. No domínio das ciências físicas, por exemplo, as grandes descobertas, aquelas que abriram realmente novas estradas e imprimiram novos rumos à ciência, foram feitas, quase sempre, em laboratórios relativamente modestos e desprovidos de grandes recursos materiais e nesse sentido a descoberta da radioatividade constitui um dos exemplos mais frisantes. Em todos os casos, porém, tais descobertas foram sempre realizadas por pessoas inteiramente dedicadas à pesquisa desinteressada, pessoas certamente dotadas de qualidades e aptidões especiais, adquiridas no trato quotidiano com a investigação da natureza, vivendo num ambiente de elevada tradição cultural e em condições que lhes permitam consagrar a totalidade de seu tempo e de sua vida aos estudos de suas preferências pessoais.

Daí concluímos que o que importa sobretudo é a criação e a manutenção de centros de pesquisa,dotados por certo dos recursos materiais indispensáveis à realização de trabalhos teórico e experimentais, mas nos quais a condição mais indispensável é permitir que um grupo de pessoas, possuindo a rara e preciosa vocação científica, possam consagrar-se inteiramente à investigação, sem que precisem desviar suas preocupações e seus esforços para o exercício de outras 
atividades que lhes assegurem os meios necessários à própria subsistência e a de suas famílias.

Em todos os países civilizados tais centros existem e são cuidadosamente mantidos e preservados, nas universidades, nas escolas superiores, nos institutos de tecnologia, ou em outras instituições e fundações especialmente organizadas para a sua manutenção.

Além de laboratórios bem aparelhados e de uma suficiente liberdade imprescindível à aplicação de recursos financeiros à pesquisa cientifica, tais centros asseguraram aos que nêles trabalham uma remuneração compatível com regime de tempo integral, permitindo-lhes assim a máxima eficiência e fecundidade no trabalho cientifico a que se consagram por completo.

A Faculdade Nacional de Filosofia, da Universidade do Brasil, possui entre as suas finalidades, explicitamente consignadas na lei, a pesquisa cientifica desinteressada. Compreende-se assim que nela se devam criar e conservar tais centros de pesquisa, dotando-os das condições indispensáveis à sua eficiente subsistência. Durante os cinco anos em que temos exercido magistério nessa Faculdade, tivemos a oportunidade de encontrar, entre os seus alunos, não poucos possuidores daquela rara e preciosa vocação que constitui a matéria prima de que são feitos os investigadores científicos. 
Alguns dêles, de tal maneira dominados por essa inclinação, conformam-se em aceitar o cargo de assistente, hoje ainda tão mal remunerado e tão desprovido de expectativas de melhor remuneração, a fim de terem uma oportunidade para a realização de seus sonhos de pesquisa original.

Graças a êsse espírito de desprendimento pelas coisas materiais da vida, tem sido possível, ao Departamento de Física desta Faculdade, reunir um pequeno grupo de elementos que constituem, assim o esperamos, uma semente fecunda da qual poderá sair talvez um dia, com o auxilio dos poderes públicos e, quem sabe, também de particulares dotados de esclarecido patriotismo, um verdadeiro centro de pesquisas cientificas (RIBEIRO, 1945).

No ano em que foi realizada a reportagem, Costa Ribeiro estava finalizando as suas pesquisas sobre dielétricos, que mesmo com as adversidades materiais do laboratório da Faculdade, levaram à descoberta de um novo fenômeno físico, assunto que trataremos no capitulo 3.

Jayme Tiomno, aluno da última turma da UDF e primeira da FNFi, explica, também, as condições de pesquisa na Faculdade:

Havia na UB dificuldade em se conseguir equipamento. Não havia bolsa de pesquisas. Fazer um laboratório era coisa muito difícil. o Costa Ribeiro conseguiu fazer pesquisas - mas, assim mesmo, não muitas -, principalmente quando foi fazer o concurso, porque 
ele comprou, como equipamento de ensino, algum equipamento mais especializado [...]. $\mathrm{Na}$ Universidade, não havia incentivo, nem condições para a pesquisa. O que havia era um incentivo no sentido de o catedrático ter seu laboratório e fazer - eventualmente - pesquisas caso tivesse tido a felicidade de montar um laboratório (TIOMNO, 1992).

Ainda na mesma reportagem é apresentado um quadro quantitativo dos discentes da FNFi entre os anos de 1939 e 1944:

Alunos que concluiram o ensino de bacharelato

\begin{tabular}{|c|c|c|c|c|c|c|}
\hline CURSOS & $\mathbf{1 9 3 9}$ & $\mathbf{1 9 4 0}$ & $\mathbf{1 9 4 1}$ & $\mathbf{1 9 4 2}$ & $\mathbf{1 9 4 3}$ & $\mathbf{1 9 4 4}$ \\
\hline Pedagogia & - & 8 & 8 & 5 & 8 & 3 \\
\hline Geog. História & - & 18 & 18 & 17 & 7 & 12 \\
\hline Filosofia & - & 1 & 1 & 3 & 3 & 1 \\
\hline Ciências Sociais & - & 4 & 8 & 6 & 4 & 1 \\
\hline L. Anglo-Germanicas & - & 9 & 5 & 22 & 5 & 12 \\
\hline L. Clássicas & - & 7 & 14 & 7 & 8 & 6 \\
\hline História Natural & - & 5 & 11 & 1 & 2 & 2 \\
\hline Química & - & 4 & 3 & 3 & 7 & 4 \\
\hline L. Neo-latinas & - & 5 & 9 & 6 & 13 & 12 \\
\hline Física & - & - & 2 & 2 & - & 1 \\
\hline Matemática & - & - & 10 & 9 & 5 & 6 \\
\hline Total & - & 61 & 89 & 81 & 62 & 60 \\
em 1a época
\end{tabular}

Tabela 1 
Alunos que concluiram o curso de licenciamento

\begin{tabular}{|c|c|c|c|c|c|c|}
\hline CURSOS & $\mathbf{1 9 3 9}$ & $\mathbf{1 9 4 0}$ & $\mathbf{1 9 4 1}$ & $\mathbf{1 9 4 2}$ & $\mathbf{1 9 4 3}$ & $\mathbf{1 9 4 4}$ \\
\hline Geog. História & 9 & 9 & 23 & 10 & 15 & 7 \\
\hline Hist. Natural & 1 & 3 & 4 & 7 & - & 2 \\
\hline L. Neolatinas & 6 & 3 & 5 & 8 & 6 & 10 \\
\hline Química & 5 & 1 & 4 & 3 & 2 & 3 \\
\hline Matemática & 2 & 1 & - & 9 & 6 & 5 \\
\hline L. Anglo-Germânicas & 6 & 7 & 9 & 5 & 19 & 4 \\
\hline Desenho & 7 & 8 & 9 & 7 & 8 & 10 \\
\hline L. Clássicas & 2 & 4 & 7 & 12 & 4 & 7 \\
\hline Ciências Sociais & 1 & 1 & 1 & 6 & 2 & 5 \\
\hline Física & - & 1 & - & 2 & 1 & - \\
\hline Pedagogia & - & - & 8 & 5 & 6 & 7 \\
\hline Filosofia & - & - & 1 & 1 & 2 & 2 \\
\hline Total & 39 & 38 & 71 & 75 & 71 & 62 \\
\hline
\end{tabular}




\section{Tabela 2}

Alunos matriculados na faculdade nacional de filosofia

\begin{tabular}{|c|c|c|c|c|c|c|}
\hline CURSOS & $\mathbf{1 9 3 9}$ & $\mathbf{1 9 4 0}$ & $\mathbf{1 9 4 1}$ & $\mathbf{1 9 4 2}$ & $\mathbf{1 9 4 3}$ & $\mathbf{1 9 4 4}$ \\
\hline Ciências Sociais & 31 & 30 & 37 & 30 & 26 & 17 \\
\hline Geografia e História & 87 & 75 & 43 & 47 & 41 & 48 \\
\hline História Natural & 29 & 21 & 14 & 6 & 9 & 5 \\
\hline Física & 5 & 4 & 5 & 4 & 3 & 7 \\
\hline Matemática & 17 & 22 & 44 & 41 & 49 & 51 \\
\hline Química & 20 & 17 & 14 & 14 & 20 & 32 \\
\hline Letras Anglo- Germânicas & 29 & 47 & 44 & 62 & 50 & 49 \\
\hline Letras Clássicas & 34 & 34 & 39 & 33 & 31 & 29 \\
\hline Letras Neolatinas & 34 & 39 & 39 & 38 & 43 & 43 \\
\hline Filosofia & 8 & 13 & 10 & 10 & 4 & 3 \\
\hline Didática & 39 & 48 & 78 & 78 & 83 & 76 \\
\hline Pedagogia & 27 & 26 & 18 & 18 & 17 & 27 \\
\hline Disciplinas isoladas & - & - & - & - & 103 & 145 \\
\hline Doutorado & - & - & 3 & 3 & 92 & 64 \\
\hline Total & 360 & 376 & 390 & 390 & 571 & 596 \\
\hline
\end{tabular}

\section{Tabela 3}

De acordo com as tabelas, observa-se o total de alunos que Costa Ribeiro ministrou suas aulas, em especial para os cursos de Física, Matemática e Química atendidos pela sua cátedra, dividindo a sua atividade docente com as suas pesquisas. É observado ainda que o curso de Física atraía poucos alunos, e, consequentemente, formavam-se pouquíssimos físicos, constituindo um problema histórico. Vê-se na tabela 1 que nos anos de 1939, 1940 e 1943 não formou-se sequer um bacharel em Física, que era pré-requisito para a licenciatura (ou licenciamento), conforme tabela 2 . 
Jayme Tiomno presenciou a fase de transição da UDF para a FNFi:

Em 1938, eu era aluno da Faculdade de Medicina. Quando entrei, em 1939, para a FNFi, continuei a fazer Medicina (1940/1941).

Em fins de 1941, o Leitão Cunha resolveu fazer a lei da desacumulação dos estudantes da Universidade do Brasil. Tivemos - nós que estávamos fazendo dois cursos - de optar por um deles.

Nessa ocasião, eu já estava bem engrenado no Curso de Física, então optei por Física, em 1941. O caminho foi este: era aluno da Medicina; meu irmão me inscreveu em Historia Natural, na UDF; cancelei essa matricula e fiz o exame de Matemática para entrar no Curso de Física da UDF. Ainda em 1939, passei para a Nacional de Filosofia (TIOMNO, 1992).

Tiomno fala da sua relação com o Costa Ribeiro: "Terminei o curso em 1941. Antes disso já estava trabalhando com o Costa Ribeiro - como monitor. Naquela época e durante muito tempo na Faculdade de Filosofia, era muito comum os monitores não ganharem nada" (TIOMNO, 1992), e completa: "Em 1942, quando a faculdade se mudou para a Casa d'Italia, eu já terminara o bacharelado e a licenciatura e tinha condições suficientes para poder ser assistente. O Costa Ribeiro tinha feito minha proposta, mas minha nomeação ainda não tinha saído" (TIOMNO, 
1992). Sobre pesquisa com o Costa Ribeiro e sua relação com o catedrático interino, Tiomno informa:

Com o Costa Ribeiro meu contrato foi como auxiliar técnico. Ele determinava um curso e me dava a liberdade de conduzi-lo como eu queria, porque confiava em mim. Isso, tanto na parte teórica, como experimental. Pesquisa propriamente dita, com ele, só mais tarde, com seu concurso de cátedra sobre o "efeito Costa Ribeiro" ou "termodielétrico" (TIOMNO,1992).

Sobre os professores italianos, Tiomno narra:

[...] veio o professor Luigi Sobrero. Dos físicos e matemáticos que vieram para o Rio, ele foi o único que tinha uma categoria internacional. Os outros, ou não tinham tanta categoria, ou vieram para cá fazer propaganda do fascismo. [...] Lembro-me do Dalberto Faggiani [...], fazendo propaganda fascista - e péssimo professor de fisica (felizmente escapei dele!) (TIOMNO, 1992).

E completa:

[...] havia o professor Mammana. Era um fascista empedernido, mas um dos melhores matemáticos aqui. Tambem o professor Achille Bassi [...], o professor Zunini- muito fraco (dava um curso de Mecânica para engenheiros, não para físicos).

Sobrero foi quem entusiasmou os estudantes para pesquisa e, desde o início, animava seminários de estudo (isso entre 1940 e 1941). Gross também participava (TIOMNO, 1992). 
No segundo ano de existência da FNFi, Elisa Frota Pessoa(1940) ingressou no curso de Física:

O início aqui no Rio, nos anos 30 , era o seguinte: quando a gente gostava de matemática durante o ginásio deveria ir para engenharia, porque não havia outra escolha, professor de matemática era engenheiro, professor de biologia era médico, etc...

No Ginásio Paulo Frontin eu tive uma sorte muito grande: o Plínio Sussekind Rocha foi ensinar física lá. Nós ficamos muito amigos, ele me auxiliou muito, porque ele me dava programa extra, ele não dava somente o que tinha no meu currículo; ele dava outras coisas para eu ir estudando e acompanhava muito. Depois, quando ele foi para a Europa, foram para o Paulo Frontin os melhores alunos formados pela Universidade do Distrito Federal (UDF). Antônio Houaiss, para ensinar literatura, o Alcides Caldas para química, o Raimundo Paesler para física, Oswaldo FrotaPessôa que, aliás, foi meu primeiro marido, para biologia; quer dizer, nós recebemos uma turma de 21, 22 anos, muito boa mesmo, toda formada pela UDF. Então nós começamos a ouvir falar mais, já desde o Plínio eu ouvia falar, da UDF. O Plínio foi o primeiro que disse: 'Se você gosta de física, você tem que fazer física mesmo. Agora já existe o curso de física na UDF'. Era a UDF antiga, a Universidade do Distrito Federal antiga. Desde aquele tempo fixei que ia fazer mesmo física. Falava-se dos físicos daquela época como Gross, Schemberg e Costa Ribeiro, mas eu não os conhecia. 
Terminando o curso, fiz exame para Física na Faculdade Nacional de Filosofia (FNF) em 1940, depois que a UDF virou Faculdade Nacional de Filosofia. Não trocou só de nome; muita coisa foi modificada e, como quase sempre acontece, para pior. Os alunos da UDF foram transferidos para a FNF, inclusive o Jayme.

[...] Alguns bons professores ficaram, e vieram os italianos. Esses italianos que vieram, com exceção do Luigi Sobrero, não deram muita contribuição. Éramos poucos alunos novos. Na Física só entrei eu. Mas juntaram as turmas de Física e Matemática, porque os dois primeiros anos eram iguais, com as mesmas matérias. Leite Lopes passou para a Física também, no meio do primeiro ano. Meu professor de primeiro ano foi Fajani (italiano), mas nesse tempo eu tinha muito contato com Costa Ribeiro, conversas na Faculdade e também na Academia de Ciências. O Oswaldo Frota-Pessôa ia à Academia de Ciências e eu ia junto com ele, e o Costa Ribeiro estava sempre lá (TIOMNO E FROTA PESSOA, 1988).

Em suma, nos depoimentos de seus primeiros ex-alunos, é observado que Costa Ribeiro teve um trabalho relevante. Isto fica registrado ainda, nos depoimento de outros ex-alunos, que fizeram suas iniciações científicas com ele. 


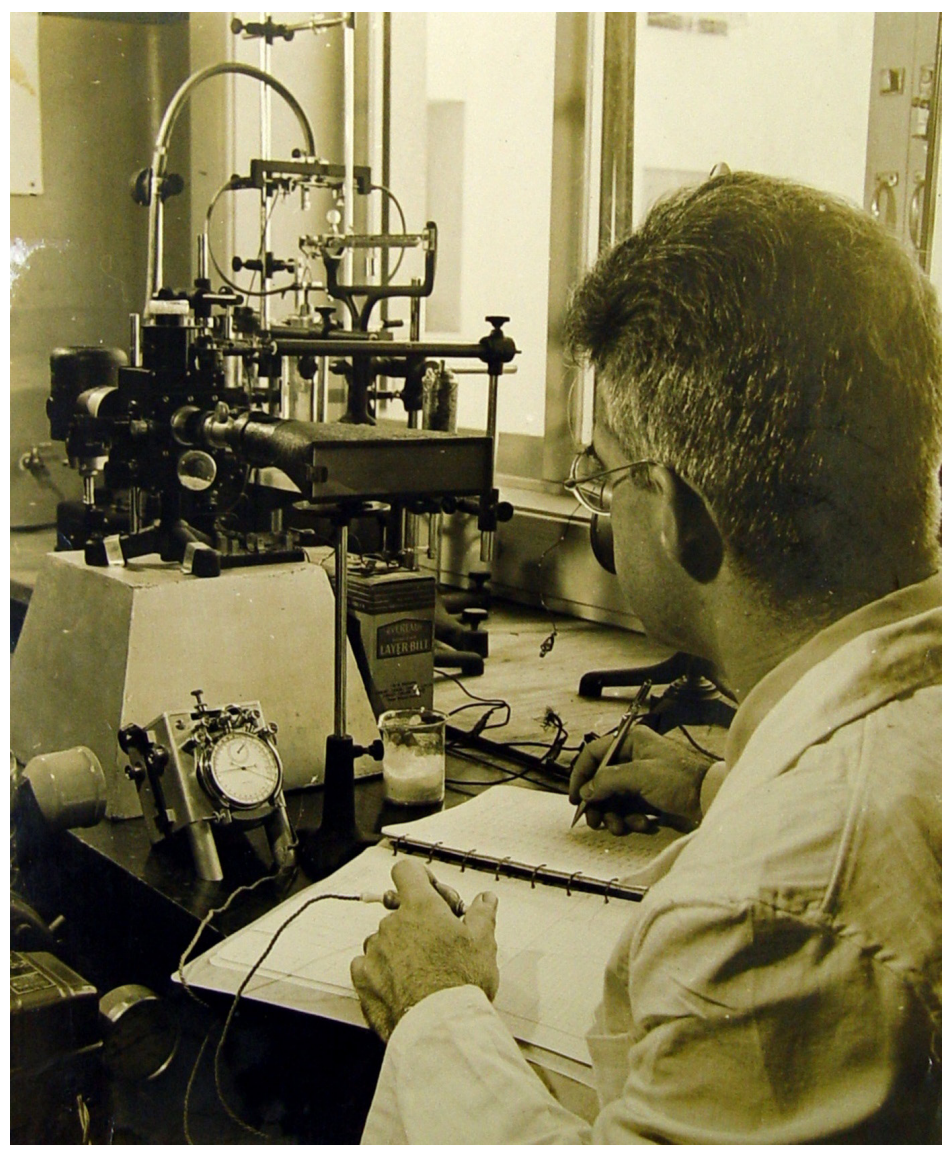

Figura 5: Costa Ribeiro pesquisando dielétricos

Fonte: acervo Costa Ribeiro-MAST 